\title{
A RADIOCARBON CHRONOLOGY OF HUNTER-GATHERER OCCUPATION FROM BODEGA BAY, CALIFORNIA, USA
}

\author{
Michael A Kennedy ${ }^{1}$ • Ann D Russell ${ }^{2}$ - Tom P Guilderson ${ }^{3}$
}

\begin{abstract}
We present a Holocene radiocarbon chronology of hunter-gatherer occupation based on contemporaneous samples of charcoal and Mytilus californianus shell recovered from 7 archaeological sites near Bodega Bay, California, USA. A series of $127{ }^{14} \mathrm{C}$ ages reveals a chronological sequence that spans from 8940-110 cal BP $(1 \sigma)$. This sequence serves as a foundation for the interpretation of behavioral change along the northern California coast over the last $9000 \mathrm{yr}$, including the adaptive strategies used by human foragers to colonize and inhabit coastal areas of this region. These ${ }^{14} \mathrm{C}$ ages will also permit us to explore major dimensions of temporal change in Holocene ocean conditions (via marine reservoir corrections) and their potential effect on the resources available to ancient hunter-gatherers.
\end{abstract}

\section{INTRODUCTION}

The evolution of hunter-gatherer maritime adaptations in western North America has been a prominent topic of discussion among archaeologists in recent years (e.g. Arnold 1992; Erlandson and Colten 1991; Erlandson and Glassow 1997; Lightfoot 1993). Although vast coastal regions of the northeastern Pacific (e.g. southern California) have been investigated in detail, our understanding of hunter-gatherer developments along the coast of northern California is limited. Previous research indicates that humans have exploited marine mammals, fish, and shellfish along the northern California shoreline since the early Holocene (Schwaderer 1992). By the end of the late Holocene, some groups remained year-round on the coast, subsisting primarily on marine resources (e.g. Gould 1975; Hildebrandt and Levulett 2002). However, a paucity of well-dated cultural deposits has hindered our understanding of these developments, particularly during the early and middle Holocene. The lack of a long and reliable chronological sequence has restricted our interpretations of behavioral change, including the adaptive strategies (such as foraging, mobility, and settlement) used by human foragers to colonize and inhabit the coastal areas of this region. These shortcomings have also hindered comparative interpretations with other coastal and inland regions in western North America.

Here, we present a Holocene radiocarbon chronology of hunter-gatherer occupation based on contemporaneous samples of charcoal and Mytilus californianus (California sea mussel) shell recovered from 7 archaeological sites near Bodega Bay, California. A series of $127{ }^{14} \mathrm{C}$ ages reveal a chronological sequence that spans from about $8940-110 \mathrm{cal}$ BP $(1 \sigma)\left(7890-160{ }^{14} \mathrm{C} \mathrm{BP}=\right.$ charcoal; $8934-101{ }^{14} \mathrm{C} \mathrm{BP}=$ shell). As part of this sequence, we report new ${ }^{14} \mathrm{C}$ dates from the stratified cave and open-air midden deposits at Duncan's Landing (CA-SON-348/H). In addition, we present ${ }^{14} \mathrm{C}$ ages from 3 middle-Holocene sites located in the Bodega Dunes, and from 3 late-Holocene sites, including Kili (CA-SON-299), the oldest known village site in the region.

Bodega Bay $\left(38^{\circ} 19^{\prime} \mathrm{N}, 123^{\circ} 03^{\prime} \mathrm{W}\right)$ is situated about $90 \mathrm{~km}$ north of San Francisco Bay, California (Figure 1). The Pacific, in conjunction with prominent geomorphological features, has given rise to a series of coastal habitats (e.g. semi-protected and protected shorelines) around Bodega Bay that are rather unique for the unprotected, surf-swept rocky shores of northern California. This stretch of coastline also lies within a zone of particularly strong seasonal upwelling between Point Reyes Peninsula and Cape Mendocino-a region characterized by high Ekman transport (Huyer 1983) and

\footnotetext{
${ }^{1}$ Department of Anthropology, University of California-Davis, Davis, California 95616, USA. Corresponding author. Email: makennedy@ucdavis.edu.

${ }^{2}$ Department of Geology, University of California-Davis, Davis, California 95616, USA.

${ }^{3}$ Lawrence Livermore National Laboratory, Center for Accelerator Mass Spectrometry, L-397, 300 East Avenue, Livermore, California 94550, USA.
} 
high coastal concentrations of the nutrients silica and phosphate (van Geen and Husby 1996). The interaction between land and sea results in a productive marine ecosystem that has attracted huntergatherers for much of the Holocene.

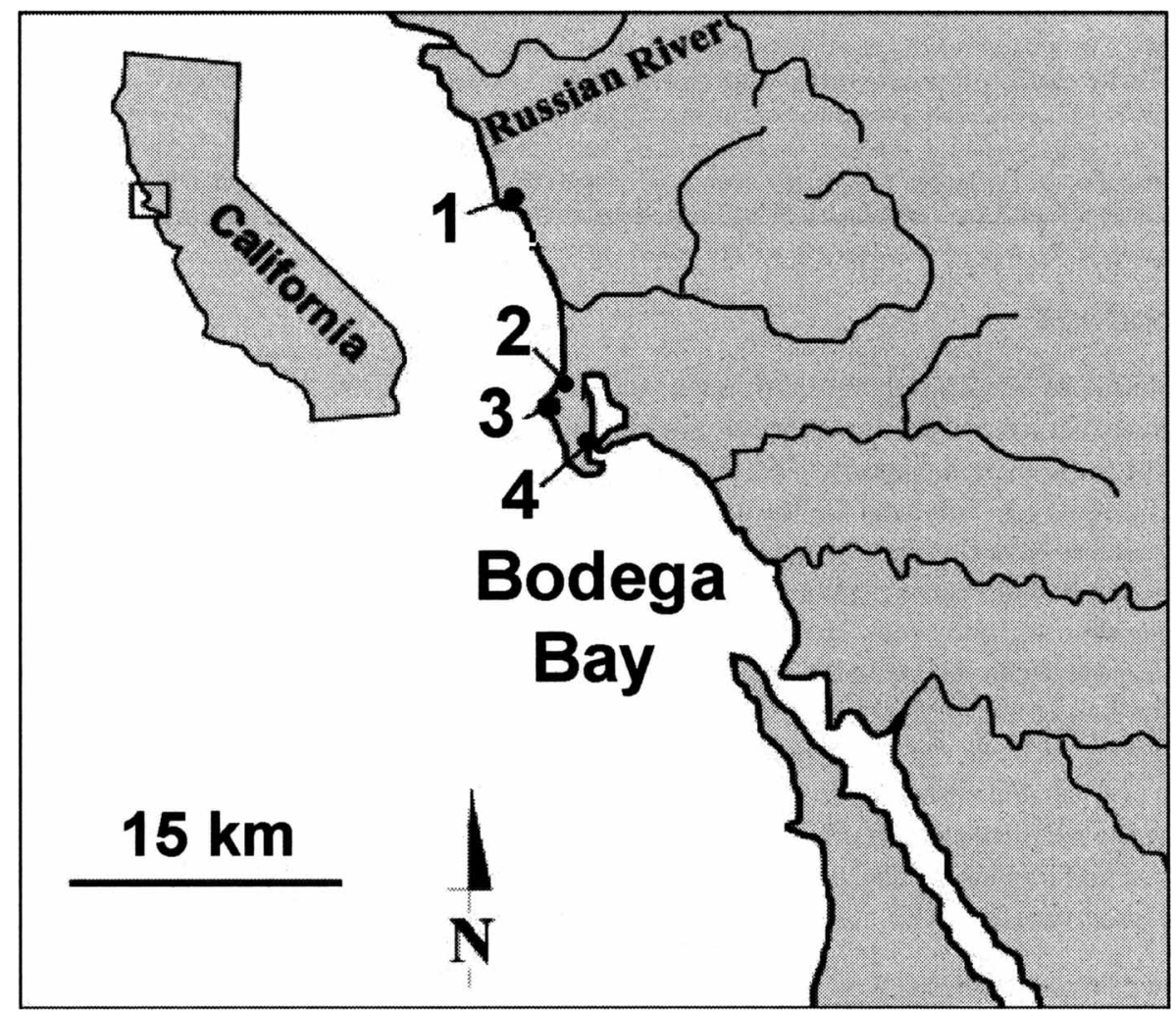

Figure 1 Location map. (1) Duncan's Landing (CA-SON-348/H); (2) Salmon Creek Beach (CA-SON-284); (3) Ocean Springs (CA-SON-2378), Two Seals (CA-SON-1735), and Mussel Point (CA-SON-327); (4) Kili (CA-SON-299), Bodega Lagoon (CA-SON-322), and Tokau (CA-SON-321).

\section{METHODS}

\section{Sample Selection}

Charcoal samples and sea mussel shells were selectively picked from 10 discrete deposits (loci) at 7 sites near Bodega Bay to assess contextual relationships between particular levels, strata, features, components, loci, and sites. However, we were also interested in choosing charcoal and shell that suited the requirements of related stable isotope studies investigating seasonal foraging strategies and ocean conditions at Bodega Bay (Kennedy et al. 2004; Kennedy 2005). Thus, the number of samples selected from each context varies.

Charcoal was selected as the terrestrial material of choice since most of the loci have small faunal assemblages. Charred and burnt twigs and twig fragments were chosen to avert the interpretative problems associated with dating old wood (Schiffer 1986). However, at times only small, amorphous-shaped charcoal pieces were available. M. californianus shells were chosen to represent the marine samples for two reasons. First, sea mussel shells are generally the most abundant faunal 
remains represented at northern California archaeological sites. Second, we wanted to select only one invertebrate species to eliminate the effect of interspecies variation in ${ }^{14} \mathrm{C}$ ages. Here, we avoided species (e.g. Macoma spp.) from low-energy habitats such as protected shorelines, which, in addition to ocean carbon, also incorporate carbon from terrestrial and atmospheric sources with different ${ }^{14} \mathrm{C}$ ages (e.g. Ingram and Southon 1996). In contrast, $M$. californianus is a filter-feeding species that lives in high-energy environments on the outer coast; thus, it has a shell chemistry that serves as a better proxy for near-shore surface water conditions.

\section{${ }^{14} \mathrm{C}$ Age Determinations}

A total of $115{ }^{14} \mathrm{C}$ determinations were submitted for analysis to the Center for Accelerator Mass Spectrometry at Lawrence Livermore National Laboratory. Shell samples were prepared for analysis by first physically removing the surface layers of the sample area with an electric Dremel ${ }^{\circledR}$ tool. Sub-samples of the newly exposed shell material were removed and chemically leached with hydrochloric acid. Approximately $10 \mathrm{mg}$ of carbonate sample was evacuated in a $10-\mathrm{mL}$ vacutainer and then reacted with $0.5 \mathrm{~mL}$ of phosphoric acid at $90^{\circ} \mathrm{C}$ to produce $\mathrm{CO}_{2}$. Charcoal samples (1-2 mg) were soaked sequentially in acid $(1 \mathrm{~N} \mathrm{HCl})$ and base $(1 \mathrm{~N} \mathrm{NaOH})$, and then given 2 acid rinses to remove $\mathrm{CO}_{2}$ that may have been absorbed during the alkaline bath. This bath sequence removed adhering humic and fulvic acids, as well as secondary carbonates. The samples were subsequently given 3 deionized water baths and dried. Samples were then loaded into quartz tubes with copper oxide $\left(\mathrm{CuO}_{2}\right)$ and silver $(\mathrm{Ag})$ powder, sealed, and combusted at $900{ }^{\circ} \mathrm{C}$.

Thereafter, both charcoal and shell $\mathrm{CO}_{2}$ were reduced to graphite using an iron catalyst and $\mathrm{H}_{2}$ gas (Vogel et al. 1987). The resulting graphite was pressed into individual aluminum target holders and measured for ${ }^{14} \mathrm{C}$ content by accelerator mass spectrometry (AMS) (Davis et al. 1990). ${ }^{14} \mathrm{C}$ ages were calculated following Stuiver and Polach (1977) from fraction modern calculated from the measured ${ }^{14} \mathrm{C} /{ }^{13} \mathrm{C}$ ratios (Southon, unpublished data; see Guilderson et al. 2003) in a manner similar to that of Donahue et al. (1990). In addition, $12{ }^{14} \mathrm{C}$ samples were submitted to Beta Analytic, Inc., Laboratory (Miami, Florida, USA) for analysis and were subject to a similar pretreatment process. To produce the radiometric dates, sample carbon was synthesized to benzene $(92 \%) \mathrm{C}$ and measured for ${ }^{14} \mathrm{C}$ content in a scintillation spectrometer, and the ${ }^{14} \mathrm{C}$ age was calculated. All charcoal ${ }^{14} \mathrm{C}$ ages were calibrated with the atmospheric and marine calibration curves used in CALIB v 4.3 (Stuiver et al. 1998a, b). To account for the regional reservoir effect, the modern mean regional $\Delta R(267 \pm 19$ yr) suggested for the northern California coast was subtracted from each shell ${ }^{14} \mathrm{C}$ age prior to calculation (Stuiver and Reimer 1993, CALIB v 4.3).

\section{ARCHAEOLOGICAL SITES AND SAMPLING}

In this section, we describe the archaeological sites and sampling strategies. Contextual details of the samples chosen for dating are given in Figures 2 and 3 and the Appendix. All sample depths are reported as below surface measurements $(\mathrm{cm})$ unless noted otherwise.

\section{Duncan's Landing (CA-SON-348/H)}

Duncan's Landing $\left(38^{\circ} 23^{\prime} 42^{\prime \prime} \mathrm{N}, 123^{\circ} 5^{\prime} 40^{\prime \prime} \mathrm{W}\right)$ is a large multi-component midden site situated on a rocky point protruding from the shoreline about $6 \mathrm{~km}$ south of the Russian River (Figure 1). The ancient uplifted sea cave (Duncan's Point Cave) located on the site contains one of the most significant records of hunter-gatherer maritime adaptations along the California coast (Erlandson 1994). In 1989, the California State Department of Parks and Recreation excavated a $1.5 \times 1.5-\mathrm{m}$ test unit inside Duncan's Point Cave as part of a site protection project (Schwaderer 1992). The excavation 


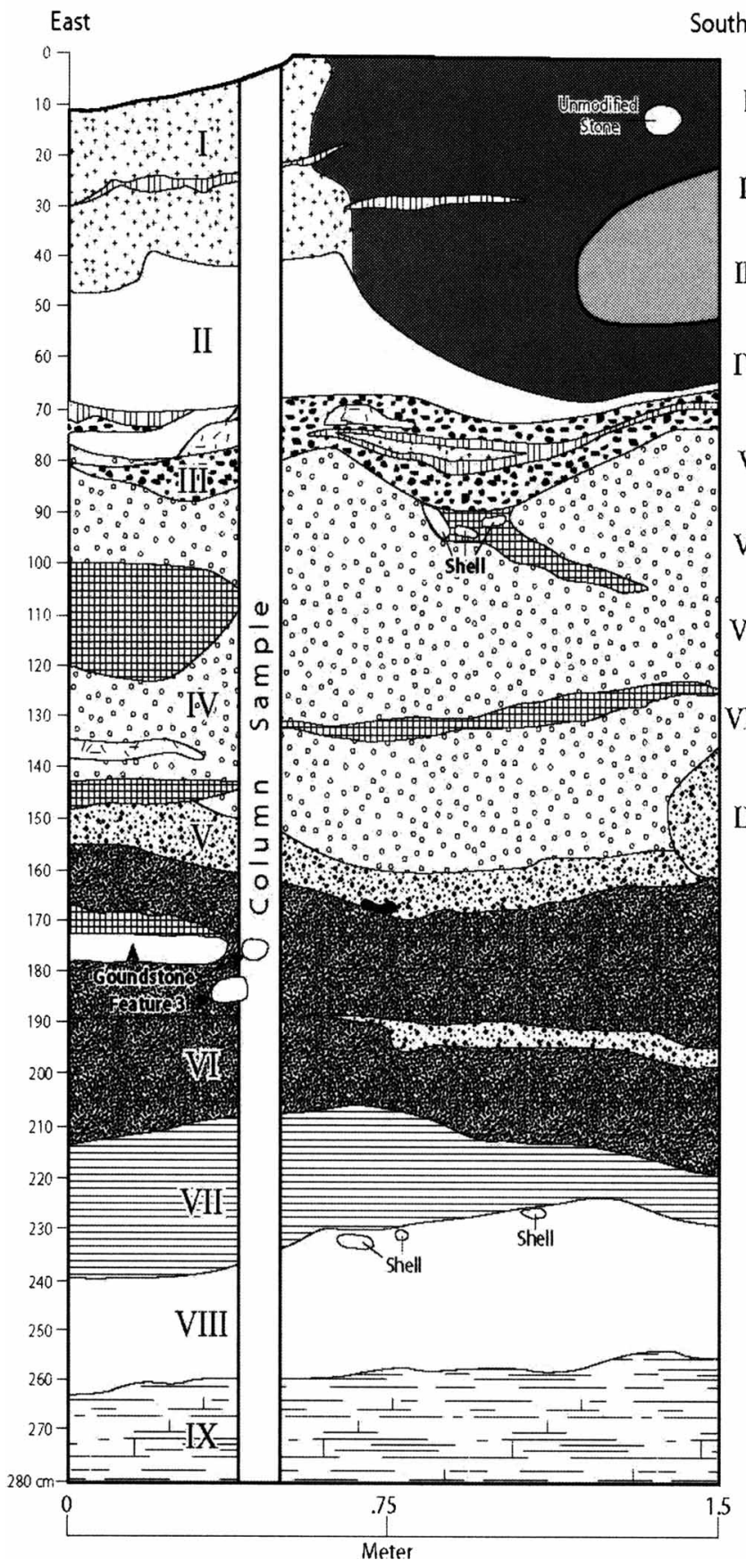

south

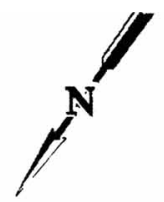

$\because \quad$ Loose, dry, dark brown $\therefore$ (1OYR 3/1) midden with shell.

III

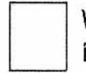

Whole shell and large fragments in loose, gray (10YR 5/1) midden.

III $\because \vdots$

Compacted, gray-brown (10YR 5/2) midden with lenses of charcoal, ash, and burned shell.

IV $\because \because$ Interbedded layers of shell and dark grayish brown (10YR 3/2) midden.

V 3 Dark grayish-brown (10YR 3/2) sandy loam.

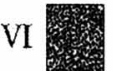

Dark grayish brown (10YR 4/2) midden with crushed shell

VII

Crushed shell with very little gray-brown (10YR 5/2) midden.

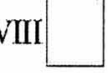

Transition between VII and IX: Brown (10YR 4/3) sandy loam/midden with shell.

IX $\rightleftharpoons$ Brown (10YR 4/3) sandy clay loam.Very little shell.

Pit fill, consisting of a loose mixture of dark brown (10YR 3/1) midden and randomly oriented shell fragments.

Dark brown (10YR 4/3) midden, sparse shell content.

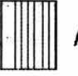

Ash and/or burned shell.

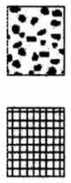

Charcoal.

Shell pocket; no midden.

Dark grayish-brown (10YR 3/2)

6. sandy clay loam similar to Stratum V.

Figure 2 Stratigraphic profile of Duncan's Landing (CA-SON-348/H), Duncan Point's Cave (Locus A), Test Unit, Southeast Wall (after Schwaderer 1992: Figure 3.1). 


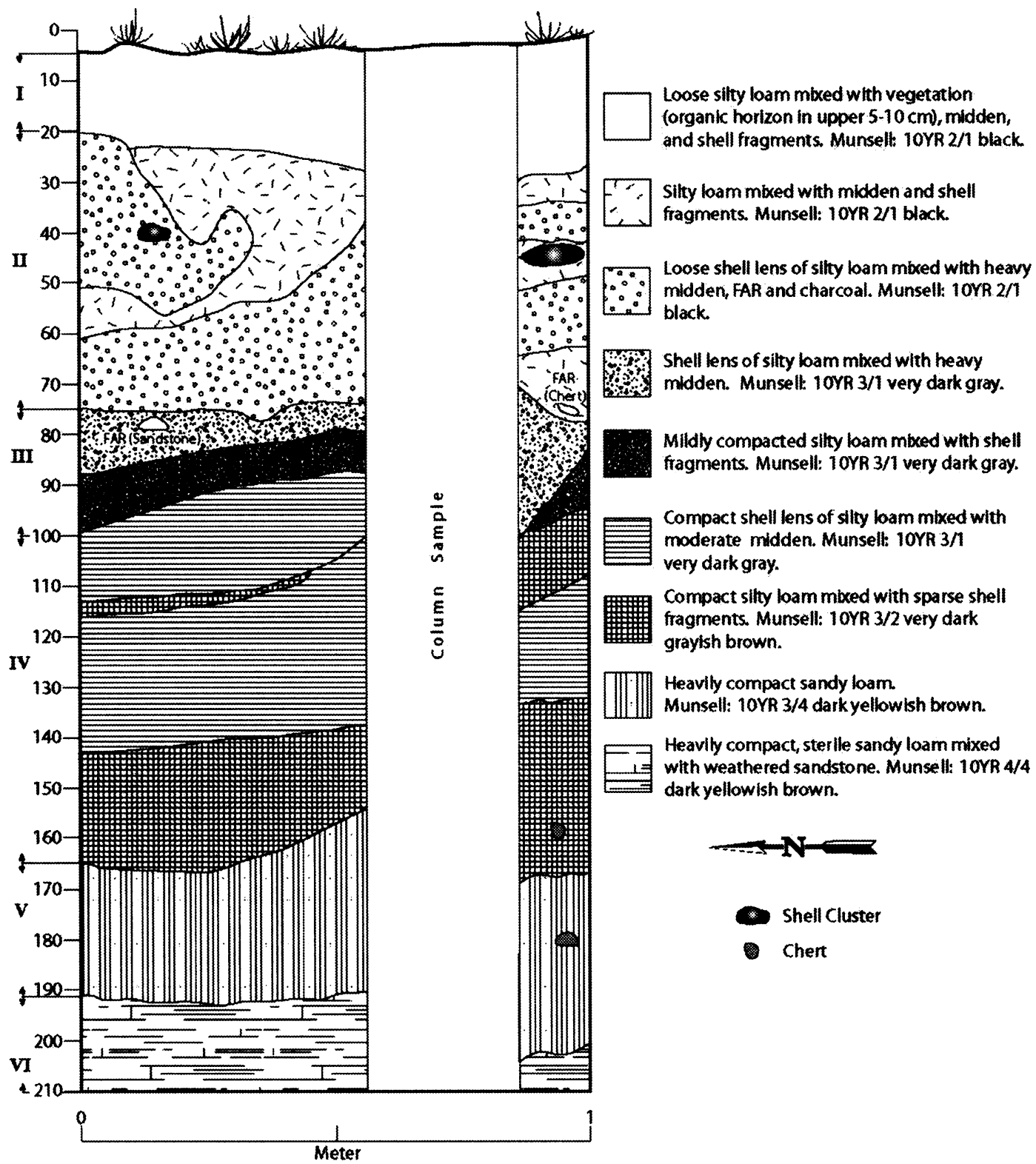

Figure 3 Stratigraphic profile of Duncan's Landing (CA-SON-348/H), Open-air Midden (Locus B), Unit F, East Wall.

revealed that the upper $60 \mathrm{~cm}$ of the deposit was heavily disturbed, yet the remaining deposit was remarkably well preserved up to a depth of nearly $3 \mathrm{~m}$. Five cultural/temporal components (discrete occupation periods) were identified and a series of $7{ }^{14} \mathrm{C}$ assays indicated a chronological sequence dating from about $9000-3000{ }^{14} \mathrm{C} \mathrm{BP}$.

In 1997, the University of California (UC)-Davis, Archaeological Field School identified 2 cultural strata (components $\mathrm{A}$ and $\mathrm{B} 1$ ) in up to $1.5 \mathrm{~m}$ of heavy deposit at Locus $\mathrm{B}$, the open-air midden area about $150 \mathrm{~m}$ northeast of the cave. Temporally sensitive artifacts (projectile points and a marine shell bead) recovered from the excavation units $(1 \times 1 \mathrm{~m})$ suggested occupation between $\sim 1500-250 \mathrm{BP}$. 


\section{Duncan's Landing, Duncan's Point Cave, Locus A}

To better define the chronology of the deposits and components inside Duncan's Point Cave, we selected specimens from column sample levels excavated in 1989 from the southeast wall of the original test unit (Figure 2). Charcoal samples $(n=18)$ and sea mussel shells $(n=25)$ were handpicked from the archived matrix curated at the California State Archaeological Collections and Research Facility, Sacramento, California, USA. We selected samples from levels that corresponded to strata II-VIII and cultural components 2-5 as reported by Schwaderer (1992). The small volume $\left(1000 \mathrm{~cm}^{3}\right)$ of matrix within each 10 -cm level gave us reasonable confidence that the shell and charcoal samples were closely associated despite the use of arbitrary excavation levels.

\section{Duncan's Landing, Open-air Midden, Locus B}

We obtained ${ }^{14} \mathrm{C}$ assays on charcoal $(n=13)$ and sea mussel shells $(n=13)$ selected from the waterscreened column sample matrix excavated along the east wall of Unit F, strata II-V (Figure 3). Specimens were chosen from arbitrary $5-\mathrm{cm}$ levels $\left(4500 \mathrm{~cm}^{3}\right)$ from the archived collection at the UCDavis Department of Anthropology Museum.

\section{The Bodega Dune Sites}

The Bodega Dune sites, Ocean Springs (CA-SON-2378), Two Seals (CA-SON-1735), and Salmon Creek Beach (CA-SON-284), are 3 shell-bearing sites situated along the lee side of the Salmon Creek Beach foredune (Figure 1). The sites are comprised of a series of small camps (loci) that were used for the purpose of processing seafood (mainly shellfish, fish, and marine plants). The sites were only recently recorded as they are isolated in the sand dunes and deflated. In 1999, the UC-Davis Archaeological Field School conducted excavations at several loci and collected samples. Levels were excavated from $2 \times 2-\mathrm{m}$ units in arbitrary 10-cm (at Salmon Creek Beach) and 20-cm (at Ocean Springs and Two Seals) levels since the matrices consisted of unconsolidated, windblown dune sand mixed with fragments of shell. Few formal tools were encountered and the lack of time-sensitive artifact types precluded temporal placement of the deposits.

\section{Ocean Springs (CA-SON-2378), Locus SM1}

Ocean Springs $\left(38^{\circ} 19^{\prime} 19^{\prime \prime} \mathrm{N}, 123^{\circ} 4^{\prime} 21^{\prime \prime} \mathrm{W}\right)$ is located near a freshwater spring and a strip of rocky shoreline. Excavations were conducted at 3 loci, two of which are reported here (loci SM1 and SM2). At Locus SM1, the deposit reached depths of over $60 \mathrm{~cm}$. Here, a charcoal fragment $(n=1)$ and a bulk sample of sea mussel shells $(n=1)$ were chosen from a 1-L matrix sub-sample excavated from the center of Unit $A$ in the upper portions of Level $3(41-45 \mathrm{~cm})$.

\section{Ocean Springs (CA-SON-2378), Locus SM2}

At Ocean Springs, Locus SM2, we selected charcoal $(n=3)$ and sea mussel shells $(n=2)$ excavated from 2 cooking features in Unit A. Additionally, 1 shell sample $(n=1)$ was chosen from an 1/8" field screen of Unit A, Level $1(0-20 \mathrm{~cm})$.

\section{Two Seals (CA-SON-1735), Locus SM1}

Two Seals $\left(38^{\circ} 19^{\prime} 44^{\prime \prime} \mathrm{N}, 123^{\circ} 4^{\prime} 10^{\prime \prime} \mathrm{W}\right)$ is located midway along Salmon Creek Beach. Locus SM1 represents the densest deposit, and despite being heavily deflated, 3 cooking features were encountered during the excavations. Charcoal samples $(n=4)$ and a sea mussel shell fragment $(n=1)$ were picked from the flotation remains of the 3 cooking features. Two shell samples $(n=2)$ were chosen from the $1 / 8^{\prime \prime}$ field screens of units $F$ and $B$, Level $2(21-40 \mathrm{~cm})$. 


\section{Salmon Creek Beach (CA-SON-284), Locus SM1}

The Salmon Creek Beach site $\left(38^{\circ} 20^{\prime} 24^{\prime \prime} \mathrm{N}, 123^{\circ} 3^{\prime} 58^{\prime \prime} \mathrm{W}\right)$ is situated about $1.5 \mathrm{~km}$ south of the present-day mouth of Salmon Creek. More than $50 \mathrm{~cm}$ of deposits were revealed at loci SM1 and SM2. At Locus SM1, charcoal samples $(n=2)$ were selected from 1-L matrix sub-samples from the center of Unit B, the upper portion of Level $2(11-15 \mathrm{~cm})$, and from the center of Unit C, upper portion of Level $5(41-45 \mathrm{~cm})$. Sea mussel shells $(n=2)$ were chosen from the $1 / 8^{\prime \prime}$ field screens of Unit B, Level $2(11-20 \mathrm{~cm})$ and Unit C, Level $11(101-110 \mathrm{~cm})$.

\section{Salmon Creek Beach (CA-SON-284), Locus SM2}

At Salmon Creek Beach, Locus SM2, a charcoal sample $(n=1)$ was chosen from a matrix subsample removed from the center of Unit A, upper portions of Level $2(11-15 \mathrm{~cm})$. Two sea mussel shells $(n=2)$ were selected from the $1 / 8^{\prime \prime}$ field screens of Unit A, Level $2(11-20 \mathrm{~cm})$ and Level 10 $(91-95 \mathrm{~cm})$.

\section{Mussel Point (CA-SON-327)}

The Mussel Point site $\left(38^{\circ} 19^{\prime} 23^{\prime \prime} \mathrm{N}, 123^{\circ} 4^{\prime} 40^{\prime \prime} \mathrm{W}\right)$ is an eroding camp perched along the cliffs on the northernmost tip of the Bodega Headland (Figure 1). Wind and wave action have destroyed the majority of the site. However, enough deposit remained to permit excavation of a $1 \times 1-\mathrm{m}$ test unit and column sample by the UC-Davis Archaeological Field School in 1999. Since the matrix consisted of unconsolidated dune sand intermixed with shell fragments and other cultural material, excavation was conducted in arbitrary $5-\mathrm{cm}$ (column sample) and 10-cm (Unit A) levels. The limited depth of the deposit (about $40 \mathrm{~cm}$ ) suggests short-term occupation. Temporal placement was not known as temporally diagnostic artifacts were not encountered.

\section{Mussel Point, Locus SM1}

We collected charcoal $(n=2)$ and sea mussel shells $(n=3)$ from the flotation remains of a $30 \times 30$ $\mathrm{cm}$ column sample taken along the eroded face of the deposit. Samples were chosen from levels 5 $(71-75 \mathrm{~cm}), 6(76-80 \mathrm{~cm})$, and $7(81-85 \mathrm{~cm})$. One charcoal sample $(n=1)$ was selected from a 1-L matrix sub-sample removed from the center of Unit A, upper portions of Level $3(21-25 \mathrm{~cm})$. One sea mussel sample $(n=1)$ was chosen from an 1/8" field screen of Unit A, Level $3(21-30 \mathrm{~cm})$.

\section{Kili (CA-SON-299)}

CA-SON-299 $\left(38^{\circ} 19^{\prime} 21^{\prime \prime} \mathrm{N}, 123^{\circ} 3^{\prime} 26^{\prime \prime} \mathrm{W}\right)$ is a large, dense shell midden situated along the protected shores of Bodega Lagoon (Figure 1). The UC Archaeological Survey excavated the site in 1949 and 1950 as part of a salvage project prior to its destruction by the landowner (Fenenga 1948; Greengo 1951; Riddell 1948). The excavations revealed that the deposit was up to $4 \mathrm{~m}$ deep and contained a highly varied artifact assemblage as well as human interments. Speculation on the age of CA-SON299 has been largely based on cross-dating with Middle Horizon (about 4000-1500 BP) sites from the North Coast Range and San Francisco Bay region (Beardsley 1954; Fredrickson 1973; Greengo 1951; Meighan 1955). Based on artifacts (e.g. shell beads) and other cultural similarities (such as human interment practices) with these sites, Davis and Treganza (1959) propose that the uppermost levels date between 3000-2500 BP, and suggest the lowermost levels are possibly older. Ethnographic documents and site records indicate CA-SON-299 was also the Native American settlement Kili (Collier and Thalman 1996; Fenenga 1948; Riddell 1948).

Sea mussel shells were chosen from the archived remains curated at the Phoebe A Hearst Museum of Anthropology, UC-Berkeley. Charcoal excavated from Kili was discarded from the museum collection in 1955 and therefore was not available for dating. 


\section{Kili, Trench F}

There were only 7 sea mussel shells $(n=7)$ with provenience information available for ${ }^{14} \mathrm{C}$ dating and the stable isotope studies. The UC Archaeological Survey collected the specimens from Trench $\mathrm{F}$ in 1949. The shells are from 12" levels excavated from $60 \times 60$ " units ("pits") within the trench (Fenenga 1951; Greengo 1950, 1951). Six sea mussel shells are from Pit F-2. One shell is from Pit F-5.

\section{Kili, Unknown Provenience}

Since only a limited number of sea mussel shells with provenience information were suitable for ${ }^{14} \mathrm{C}$ dating and the stable isotope analyses, we selected 10 sea mussel shells $(n=10)$ from unknown contexts. The UC Archaeological Survey most likely recovered the specimens in 1949 or 1950 . Method of field collection is unknown.

\section{Bodega Lagoon (CA-SON-322)}

The Bodega Lagoon site $\left(38^{\circ} 18^{\prime} 58^{\prime \prime} \mathrm{N}, 123^{\circ} 3^{\prime} 30^{\prime \prime} \mathrm{W}\right)$ is a food processing location associated with the nearby ethnographic and prehistoric settlement Tokau (CA-SON-321) (Figure 1). Auger testing by the UC-Davis Archaeological Field School (1998) revealed up to 2-3 m of dense deposit was buried beneath more recent dune sand; however, test unit excavations mainly tested the upper portions of the midden. Units $(1 \times 1 \mathrm{~m})$ were excavated in arbitrary 10 -cm levels. Temporally sensitive marine shell beads and a projectile point suggested an occupation between about 500-100 BP for the upper portions of the deposit.

\section{Bodega Lagoon, Locus SM1}

Charcoal specimens $(n=5)$ and sea mussel shells $(n=4)$ were chosen from the $1 / 8^{\prime \prime}$ field screens of Unit E, Level $12(141-150 \mathrm{~cm})$. One twig fragment $(n=1)$ and a sea mussel shell fragment $(n=1)$ were selected from the flotation remains of a 1-L matrix sub-sample excavated from the northwest corner of Unit D, Level $12(111-115 \mathrm{~cm})$. One burnt twig $(n=1)$ was chosen from a 1-L matrix subsample removed from the center of Unit B, Level $12(111-115 \mathrm{~cm})$.

\section{RESULTS AND DISCUSSION}

The Duncan's Point Cave (Locus A) sequence shows a very strong correlation between depth and ${ }^{14} \mathrm{C}$ age as both charcoal $\left(r^{2}=0.83 ; p<0.0001\right)$ and sea mussel shell $\left(r^{2}=0.88 ; p<0.0001\right)$ dates become progressively older with depth (Figure 4). The sequence shows remarkable consistency and suggests that the basic integrity of the deposit is intact. The calibrated charcoal and shell ages indicate an occupation period between 8930-2870 cal BP ( $1 \sigma)$ and 8980-3110 cal BP ( $1 \sigma)$, respectively, in general agreement with the original ${ }^{14} \mathrm{C}$ dates reported by $\mathrm{Sch}$ aderer $(1992)$. The ${ }^{14} \mathrm{C}$ ages from the Open-air Midden (Locus B) at Duncan's Landing also reveal strong correlations as both charcoal $\left(r^{2}=0.75 ; p<0.0001\right)$ and sea mussel shell $\left(r^{2}=0.35 ; p<0.05\right){ }^{14} \mathrm{C}$ ages become older with depth (Figure 5). The calibrated charcoal ages indicate Locus B was occupied between 1180-350 cal BP $(1 \sigma)$, while the calibrated shell ages indicate occupation from 820-110 cal BP ( $1 \sigma)$.

The Bodega Dune sites reveal a discrete suite of charcoal and sea mussel shell ${ }^{14} \mathrm{C}$ ages related to a series of middle-Holocene processing camps used for short periods of time (i.e. up to a few centuries). The calibrated charcoal ${ }^{14} \mathrm{C}$ ages at Ocean Springs, Locus SM2, range from 5310-4880 cal BP $(1 \sigma)$, while the calibrated shell ${ }^{14} \mathrm{C}$ ages range from 5230-4810 cal BP $(1 \sigma)$. At Ocean Springs, Locus SM1, the calibrated charcoal ${ }^{14} \mathrm{C}$ age ranges from $4510-4410 \mathrm{cal} \mathrm{BP}(1 \sigma)$ and the calibrated shell ${ }^{14} \mathrm{C}$ age ranges from $4610-4430 \mathrm{cal}$ BP $(1 \sigma)$. The grouping of shell and charcoal ${ }^{14} \mathrm{C}$ ages 
Duncan's Point Cave (CA-SON-348/H), Test Unit, Column Sample

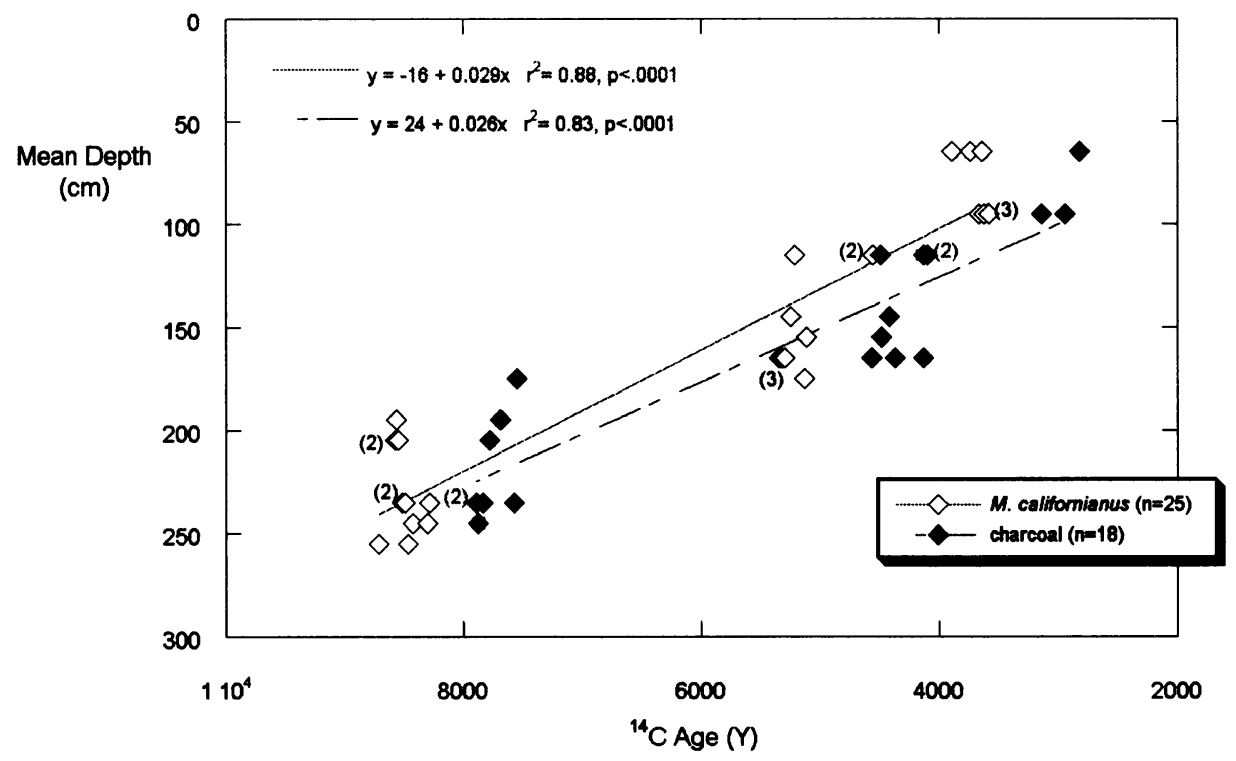

Figure 4 Charcoal and Mytilus californianus shell ${ }^{14} \mathrm{C}$ ages $(1 \sigma)$ and depth $(\mathrm{cm})$ of recovery from Duncan's Landing (CA-SON-348/H), Duncan Point's Cave (Locus A), Test Unit, Column Sample. Note: Standard deviations are smaller $(1 \sigma)$ than symbol widths.

\section{Duncan's Landing (CA-SON-348/H), Locus B, Unit F, Column Sample}

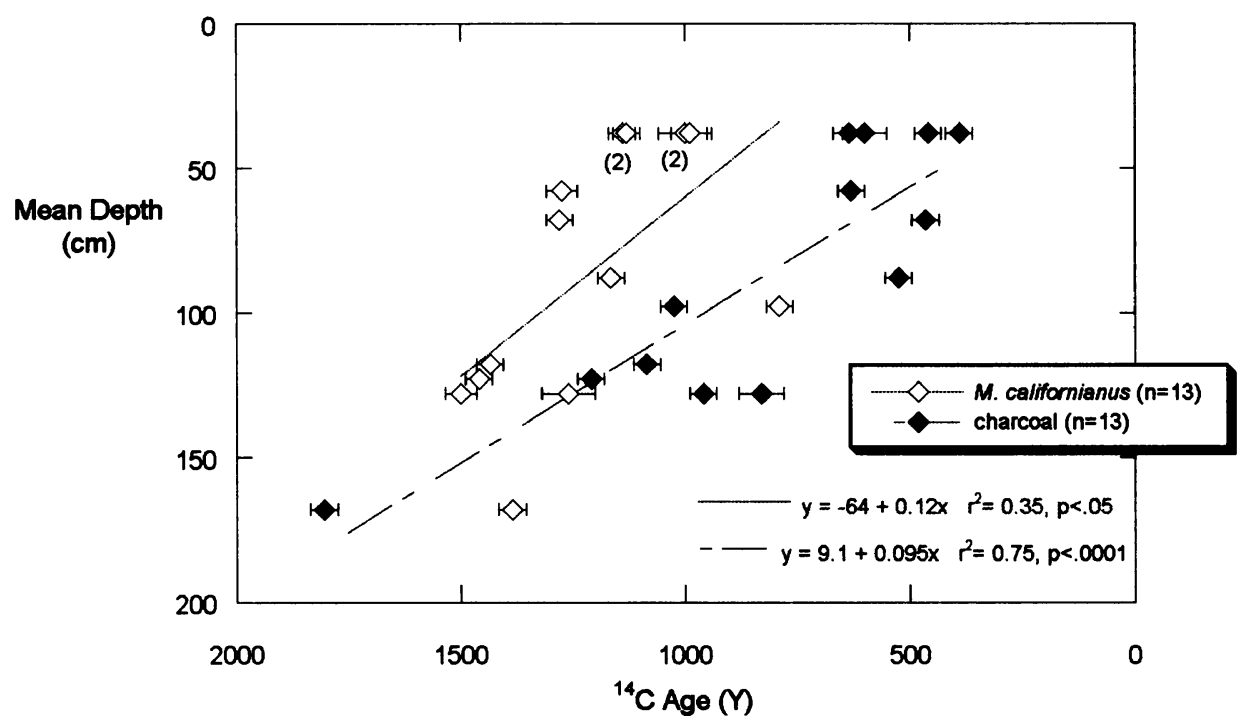

Figure 5 Charcoal and Mytilus californianus shell ${ }^{14} \mathrm{C}$ ages $(1 \sigma)$ and depth $(\mathrm{cm})$ of recovery from Duncan's Landing (CA-SON-348/H), Locus B (Open-air Midden), Unit F, Column Sample. 
from Two Seals (Locus SM1) is also extremely consistent. The calibrated charcoal ${ }^{14} \mathrm{C}$ ages range from 4570-4100 cal BP $(1 \sigma)$ and calibrated shell ${ }^{14} \mathrm{C}$ ages range from $4590-4420 \mathrm{cal} \mathrm{BP}(1 \sigma)$ and are contemporaneous with the ages obtained from Ocean Springs, Locus SM1. Likewise, the ${ }^{14} \mathrm{C}$ ages from the Salmon Creek Beach site also indicate great consistency. The calibrated charcoal and shell ${ }^{14} \mathrm{C}$ age ranges from loci SM1 and SM2 indicate occupation between $4420-4090 \mathrm{cal}$ BP (1 $\left.\sigma\right)$ and $4420-4070$ cal BP $(1 \sigma)$, respectively, coeval with Ocean Springs, Locus SM1 and Two Seals, Locus SM1.

Similarly, the charcoal and sea mussel shell ${ }^{14} \mathrm{C}$ ages from Mussel Point, Kili, and Bodega Lagoon reveal 3 discrete late-Holocene occupations. At Mussel Point (Locus SM1), the calibrated charcoal ages range from $2350-2160 \mathrm{cal} \mathrm{BP}(1 \sigma)$, while the calibrated shell ages range from $2180-1830 \mathrm{cal}$ BP $(1 \sigma)$. At the village site Kili, we observe a tight sequence of shell ${ }^{14} \mathrm{C}$ ages despite the use of specimens without contextual information. The calibrated ages range from 1990-1490 cal BP (1 $\sigma)$. The Bodega Lagoon (Locus SM1) site also exhibits a series of ${ }^{14} \mathrm{C}$ ages from a discrete deposit. The calibrated charcoal ${ }^{14} \mathrm{C}$ ages range from $480-0 * 1$ cal BP $(1 \sigma)$ and the calibrated shell ages range between $430-140$ cal BP $(1 \sigma)$.

\section{CONCLUSIONS}

In sum, the suite of ${ }^{14} \mathrm{C}$ dates reveal that the sampled loci are relatively well preserved and contain a major proportion of their original integrity, although some mixing is apparent within a few of the deposits. This sequence serves as a foundation from which diachronic comparisons between components and their constituents can be used to develop a local cultural sequence. In addition, since the ${ }^{14} \mathrm{C}$ dates were conducted on groupings of closely associated charcoal and sea mussel shell, they also provide important paleoceanographic information about the past by promoting the development of marine reservoir corrections. These estimates will aid in the calibration of regional ${ }^{14} \mathrm{C}$ ages from ancient marine remains and facilitate the investigation of trends in ocean conditions at the time of occupation (e.g. Ingram 1998; Kennett et al. 1997). These data will permit us to explore major dimensions of temporal change in Holocene marine conditions and their potential effect on the resources that were available to hunter-gatherers.

\section{ACKNOWLEDGMENTS}

This research was supported by funding from the UC Office of the President-Institute of Geophysics and Planetary Physics program, the California Department of Parks and Recreation (contract $\mathrm{nr}$ C0139025), and aided by a Grant-in-Aid of Research from Sigma Xi, The Scientific Research Society. ${ }^{14} \mathrm{C}$ analyses were performed under the auspices of the US Department of Energy by the UC Lawrence Livermore National Laboratory (contract nr W-7405-Eng-48). We thank the California State Archaeological Collection and Research Facility and the Phoebe A Hearst Museum of Anthropology, UC-Berkeley, for access to the archived collections from CA-SON-348/H and CA-SON299 (respectively); the UC-Davis Bodega Marine Reserve (contribution nr 2231, Bodega Marine Laboratory, University of California at Davis) and California State Department of Parks and Recreation for access to the field sites; and the UC-Davis Archaeological Field School for assistance in collecting the field samples. We express gratitude to $\mathrm{R}$ Bettinger and $\mathrm{K}$ Lightfoot for comments on earlier drafts of this manuscript, and are grateful to $\mathrm{H}$ Spero for numerous suggestions during the formative stages of this research. We would also like to acknowledge J Beaton, L Chiea, P Connors, R Elston, G Farris, D Harris, K Lindhahl, B McEneaney, B Parkman, P Shannon, D Winter, A Yengoyan, and $\mathrm{P}$ Zermeño for their assistance during various phases of this research.

$1 *$ - represents a negative ${ }^{14} \mathrm{C}$ age BP as reported by CALIB v 4.3 (Stuiver and Reimer 1993). 


\section{REFERENCES}

Arnold JE. 1992. Complex hunter-gatherer-fishers of prehistoric California: chiefs, specialists, and maritime adaptations of the Channel Islands. American Antiquity 57(1):60-84.

Beardsley RK. 1954. Temporal and areal relationships in central California archaeology. University of California Archaeological Survey Reports 24:1-62.

Collier ME, Thalman SB. 1996. Interviews with Tom Smith and Maria Copa: Isabel Kelly's Ethnographic Notes on the Coast Miwok Indians of Marin and Southern Sonoma Counties, California. 2nd edition. San Rafael, California: Miwok Archaeological Preserve of Marin Occasional Papers No. 6. 543 p.

Davis JC, Proctor ID, Southon JR, Caffee MW, Heikkinen DW, Roberts ML, Moore TL, Turteltaub KW, Nelson DE, Lloyd DH, Vogel JS. 1990. LLNL/UC AMS facility and research program. Nuclear Instruments and Methods in Physics Research B 52:269-72.

Davis JT, Treganza AE. 1959. The Patterson Mound: a comparative analysis of the archaeology of site Ala328. University of California Archaeological Survey Reports 47:1-92.

Donahue DJ, Linick TW, Jull AJT. 1990. Isotope-ratio and background corrections for accelerator mass spectrometry radiocarbon measurements. Radiocarbon 32(2):135-42.

Erlandson JM. 1994. Early Hunter-Gatherers of the California Coast. New York: Plenum Press. 336 p.

Erlandson JM, Colten RH, editors. 1991. Hunter-Gatherers of Early Holocene Coastal California. Volume 1. Los Angeles: Institute of Archaeology, University of California, Los Angeles. 160 p.

Erlandson JM, Glassow MA, editors. 1997. Archaeology of the California Coast During the Middle Holocene. Volume 4. Los Angeles: Institute of Archaeology, University of California, Los Angeles. 187 p.

Fenenga F. 1948. Archaeological site survey record CASON-299. University of California Archaeological Survey. Rohnert Park, California: Northwest Information Center, Sonoma State University.

Fenenga F. 1951. Partial draft report on archaeological excavations at CA-SON-299, by Franklin Fenenga, ca. 1951. Berkeley, California: Archaeological Archives of the Phoebe A Hearst Museum of Anthropology, University of California, Berkeley.

Fredrickson DA. 1973. Early cultures of the North Coast Ranges [PhD dissertation]. Davis: University of California, Davis.

Gould RA. 1975. Ecology and adaptive responses among the Tolowa Indians of northwestern California. Journal of California Anthropology 2(2):148-70.

Greengo RE. 1950. Shell analysis of Bodega Bay, Son299. Berkeley, California: Archaeological Archives of the Phoebe A Hearst Museum of Anthropology, University of California, Berkeley.

Greengo RE. 1951. Molluscan species in California shell middens. University of California Archaeological Survey Reports 13:1-28.

Guilderson TP, Southon JR, Brown TA. 2003. High-precision AMS ${ }^{14} \mathrm{C}$ results on TIRI/FIRI turbidite. Radiocarbon 45(1):75-80.

Hildebrandt WR, Levulett VA. 2002. Late Holocene emergence of marine-focused economies in northwest California. In: Erlandson JM, Jones TL, editors. Catalysts to Complexity: Late Holocene Societies of the California Coast. Volume 6. Los Angeles: Institute of Archaeology, University of California, Los Angeles. p 303-19.

Huyer A. 1983. Coastal upwelling in the California current system. Progress in Oceanography 12(3):25984.

Ingram BL. 1998. Differences in radiocarbon age between shell and charcoal from a Holocene shellmound in northern California. Quaternary Research 49:10210.

Ingram BL, Southon JR. 1996. Reservoir ages in eastern Pacific coastal and estuarine waters. Radiocarbon 38(3):573-82.

Kennedy MA. 2005. An investigation of hunter-gatherer shellfish foraging practices: archaeological and geochemical evidence from Bodega Bay, California [PhD dissertation]. Davis: University of California, Davis.

Kennedy MA, Russell AD, Guilderson TP. 2004. Shellfish seasonal foraging strategies from Bodega Bay, California. In: Proceedings of the Society for California Archaeology. Papers Presented at the Annual Meeting of the Society for California Archaeology. Sacramento, California, 27-29 March 2003. Volume 17. Chico, California: Society for California Archaeology. p 141-150.

Kennett DJ, Ingram BL, Erlandson JM, Walker PL. 1997. Evidence for temporal fluctuations of marine radiocarbon reservoir ages in the Santa Barbara Channel region, California. Journal of Archaeological Science 24:1051-59.

Lightfoot KG. 1993. Long-term developments in complex hunter-gatherer societies: recent perspectives from the Pacific coast of North America. Journal of Anthropological Research 1:167-201.

Long A, Rippeteau B. 1974. Testing the contemporaneity and averaging radiocarbon dates. American Antiquity 39(2):205-15.

Meighan CW. 1955. Archaeology of the North Coast Ranges, California. University of California Archaeological Survey Reports 30:1-39.

Riddell F. 1948. Archaeological Site Survey Record CASON-299. University of California Archaeological Survey. Rohnert Park, California: Northwest Information Center, Sonoma State University.

Schiffer MB. 1986. Radiocarbon dating and the "old wood" problem: the case of the Hohokam chronology. 
Journal of Archaeological Science 13:13-30.

Schwaderer R. 1992. Archaeological test excavation at the Duncan's Point Cave, CA-SON-348/H. In: Jones TL, editor. Essays on the Prehistory of Maritime California. Volume 10. Davis, California: Center for Archaeological Research at Davis. University of California, Davis, Department of Anthropology. p 55-71.

Schwaderer R. 1989-1992. Duncan's Point Cave (CASON-348/H) field and laboratory records: excavation and analyses notes. Sacramento: State of California Department of Parks and Recreation, Cultural Heritage Section, Archaeology Laboratory.

Stuiver M, Polach HA. 1977. Discussion: reporting of ${ }^{14} \mathrm{C}$ data. Radiocarbon 19(3):355-63.

Stuiver M, Reimer PJ. 1993. Extended ${ }^{14} \mathrm{C}$ database and revised CALIB $3.0{ }^{14} \mathrm{C}$ age calibration program. $R a$ - diocarbon 35(1):215-30.

Stuiver M, Reimer PJ, Bard E, Beck JW, Burr GS, Hughen KA, Kromer B, McCormac G van der Plicht J, Spurk M. 1998a. IntCal98 radiocarbon age calibration, 24,000-0 cal BP. Radiocarbon 40(3):1041-83.

Stuiver M, Reimer PJ, Braziunas TF. 1998b. High-precision radiocarbon age calibration for terrestrial and marine samples. Radiocarbon 40(3):1127-51.

van Geen A, Husby DM. 1996. Cadmium in the California current system: tracer of past and present upwelling. Journal of Geophysical Research: C. Oceans 101:3489-507.

Vogel JS, Nelson DE, Southon JR. $1987 .{ }^{14} \mathrm{C}$ background levels in an accelerator mass spectrometry system. Radiocarbon 29(3):323-33.

\section{APPENDIX: ARCHAEOLOGICAL ${ }^{14} \mathrm{C}$ RESULTS}

The charcoal and $M$. californianus shell ${ }^{14} \mathrm{C}$ ages for each of the 10 Bodega Bay loci are listed below. ${ }^{14} \mathrm{C}$ assays are reported from oldest to youngest by site and locus. Charcoal ${ }^{14} \mathrm{C}$ ages are reported first, followed by the shell ages. For each date, we present a brief contextual description. For a number of samples, we provide an archaeological and stratigraphic assessment. Charcoal and shell ${ }^{14} \mathrm{C}$ ages are accompanied by calibrated spreads $(1 \sigma)$ and intercepts in the comment section.

\section{Duncan's Landing (CA-SON-348/H), Locus A (Duncan's Point Cave)}

\section{CAMS-86877}

Sample ID nr: SON 348 114-7-1

Small charcoal fragment, column

crushed shell with very little midden (VII) mixed with sandy loam/midden with shell (VIII).

Comment: 8925 (8641) 8602 cal BP (1 $\sigma)$. The calibrated spread of this sample sets initial marine resource use at the cave to at least $8900 \mathrm{cal} \mathrm{BP}$. A charcoal ${ }^{14} \mathrm{C}$ age (Schwaderer 1992; $8620 \pm 420 \mathrm{BP}$, Beta-35229) collected in 1989 from the test unit's south corner $(222 \mathrm{~cm})$ suggested greater possible antiquity; however, it was accompanied by a large error estimate.

CAMS-86880

$$
\mathbf{7 8 7 5} \pm \mathbf{4 5}
$$

SON 348 114-8-1

$\delta^{13} \mathrm{C}=-25.8 \%$

Small burned twig, column sample, upper portion of Stratum VIII, Level 23, 240-250 cm, sandy loam/midden mixed with shell.

Comment: 8748 (8634) $8595 \mathrm{cal} \mathrm{BP}(1 \sigma)$. This ${ }^{14} \mathrm{C}$ age overlaps at $1 \sigma$ and corroborates the ages of CAMS-86877 (above) and CAMS-86878 (below).

\section{CAMS-86878} $7835 \pm 35$

SON 348 114-7-2 $\delta^{13} \mathrm{C}=-26.1 \%$

Comment: 8635 (8597) 8589 cal BP $(1 \sigma)$. The $\delta^{13} \mathrm{C}$ value of this sample was estimated from CAMS-86877, above. 
CAMS-86876

$7775 \pm 35$

SON 348 114-5-1

$\delta^{13} \mathrm{C}=-24.0 \%$

Small burned twig fragment, column sample, lowest portion of Stratum VI, Level 19, 200-210 cm, dark midden mixed with crushed shell.

Comment: 8592 (8585, 8574, 8542) 8460 cal BP (1 б).

CAMS-96630

$7690 \pm 35$

SON 348 114-13-1

$\delta^{13} \mathrm{C}=-24.3 \%$

Small charcoal fragment, column sample, lower portion of Stratum VI, Level 18, 190-200 cm, dark midden mixed with crushed shell.

Comment: $8535(8444,8443,8426) 8411$ cal BP $(1 \sigma)$. This date, when compared with our other charcoal dates from between 190-260 cm, suggests that the upper portions of Component 2 extend to the middle of Stratum VI (about $190 \mathrm{~cm}$ ).

CAMS-86879

$7575 \pm 35$

SON 348 114-7-3

$\delta^{13} \mathrm{C}=-26.1 \%$

Small charcoal fragment; see CAMS-86877 (above) for 230-240-cm level description.

Comment: 8393 (8385) 8365 cal BP $(1 \sigma) . \delta^{13} \mathrm{C}$ was estimated from CAMS-86877.

CAMS-96629

SON 348 114-12-1

$7550 \pm 35$

$\delta^{13} \mathrm{C}=-23.6 \%$

Small charcoal fragment, column sample, upper portion of Stratum VI, Level 16, 170-180 cm, dark midden mixed with crushed shell.

Comment: $8388(8370) 8347$ cal BP $(1 \sigma)$. This calibrated spread overlaps at $1 \sigma$ with a charcoal sample from 230-240 cm (CAMS-86879, above); however, a shell sample (CAMS-96617, below) from the same $170-180-\mathrm{cm}$ level dates to the middle Holocene.

\section{CAMS-86873}

$4565 \pm 35$

SON 348 114-4-1

$\delta^{13} \mathrm{C}=-26.4 \%$

Small burned twig fragment, column sample, uppermost portion of Stratum VI, Level 15, $160-170 \mathrm{~cm}$, dark midden mixed with crushed shell.

Comment: 5313 (5302) 5089 cal BP $(1 \sigma)$. This ${ }^{14} \mathrm{C}$ age, along with our other charcoal dates from between $140-170 \mathrm{~cm}$ (see below), post-date the Component 3 charcoal ${ }^{14} \mathrm{C}$ age (Schwaderer 1992 ; $6260 \pm 120$ BP, Beta-35528; see also Schwaderer 1989-1992) obtained at a depth of $160 \mathrm{~cm}$ from an occupation floor/hearth (Feature 1) in the north corner of the test unit.

\section{CAMS-86871}

SON 348 114-3-2

$$
\begin{array}{r}
4490 \pm 40 \\
\delta^{13} \mathrm{C}=-25.7 \%
\end{array}
$$

Small charcoal fragment, column sample, middle portion of Stratum IV, Level 10, 110-120 cm, interbedded layers of shell and dark midden.

Comment: 5290 (5260, 5185, 5119, 5110, 5065, 5063, 5052) 5044 cal BP (1 $\sigma)$. The 110-120-cm level corresponds to Component 4 as described by Schwaderer (1992).

CAMS-96628

SON 348 114-11-1

$$
\begin{array}{r}
4485 \pm 30 \\
\delta^{13} \mathrm{C}=-27.6 \%
\end{array}
$$

Small charcoal fragment, column sample, mainly Stratum V, Level 14, 150-160 cm, a dark sandy loam. 
Comment: $5295(5278,5167,5129,5106,5070) 5048 \mathrm{cal} \mathrm{BP}(1 \sigma)$. This ${ }^{14} \mathrm{C}$ age overlaps at $1 \sigma$ with CAMS-86871, above. See CAMS-86873 (above) for comment.

\section{CAMS-96627}

$$
4415 \pm 30
$$

SON 348 114-10-1

$$
\delta^{13} \mathrm{C}=-25.4 \%
$$

Small charcoal fragment, column sample, lowest portions of Stratum IV, Level 13, 140-150 cm, interbedded layers of shell and dark midden.

Comment: 5044 (5028, 5019, 4976) 4876 cal BP (1 $\sigma)$.

\section{CAMS-86875}

$$
4370 \pm 35
$$

SON 348 114-4-3

$$
\delta^{13} \mathrm{C}=-26.4 \%
$$

Small charcoal fragment; see CAMS-86873 (above) for 160-170-cm level description.

Comment: $5026(4954,4951,4872) 4865$ cal BP $(1 \sigma) . \delta^{13} \mathrm{C}$ was estimated from CAMS-86873, above.

\section{CAMS-86874}

$$
4130 \pm 35
$$

SON 348 114-4-2

$$
\delta^{13} \mathrm{C}=-26.4 \%
$$

Small burned twig fragment; see CAMS-86873 (above) for 160-170-cm level description.

Comment: $4811(4789,4766,4616,4595,4592) 4549 \mathrm{cal} \mathrm{BP}(1 \sigma)$. This ${ }^{14} \mathrm{C}$ age is the same age as a charcoal sample (CAMS-86870, below) from the $110-120-\mathrm{cm}$ level. $\delta^{13} \mathrm{C}$ was estimated from CAMS-86873, above.

\section{CAMS-86870}

$$
4130 \pm 60
$$

SON 348 114-3-1

$$
\delta^{13} \mathrm{C}=-25.7 \%
$$

Small burned twig fragment; see CAMS-86871 (above) for 110-120-cm level description.

Comment: $4823(4789,4766,4616,4595,4592) 4530$ cal BP $(1 \sigma) . \delta^{13} \mathrm{C}$ was estimated from CAMS-86871, above.

\section{CAMS-86872}

$$
4095 \pm 30
$$

SON 348 114-3-3

$$
\delta^{13} \mathrm{C}=-25.7 \%
$$

Small charcoal fragment; see CAMS-86871 (above) for 110-120-cm level description.

Comment: 4809 (4570, 4557, 4550) 4448 cal BP $(1 \sigma) . \delta^{13} \mathrm{C}$ was estimated from CAMS-86871, above.

\section{CAMS-86868}

\section{SON 348 114-2-1}

$$
\delta^{13} \mathrm{C}=-24.5 \%
$$

Small burned twig fragment, column sample, upper portion of Stratum IV, Level 8, 90-100 cm, interbedded layers of shell and dark midden.

Comment: 3383 (3361) 3273 cal BP ( $1 \sigma)$. This sample is from the lower levels of Component 5 and is compatible with a charcoal date (Schwaderer 1992; $3400 \pm 120 \mathrm{BP}$, Beta-35226) obtained at a depth of 90-92 cm from the southwest wall of the test unit.

\section{CAMS-86869}

Small burned twig fragment; see CAMS-86868 (above) for 90-100-cm level description.

Comment: 3205 (3121) $3000 \mathrm{cal} \mathrm{BP}(1 \sigma) . \delta^{13} \mathrm{C}$ was estimated from CAMS-86868, above. 
CAMS-86867

$2820 \pm 25$

SON 348 114-1-1

$\delta^{13} \mathrm{C}=-23.5 \%$

Small charcoal fragment, column sample, largely Stratum II, Level 5, 60-70 cm, whole and large fragments of shell in loose midden.

Comment: $2951(2922,2905,2890) 2870$ cal BP $(1 \sigma)$. This is the youngest charcoal date from the undisturbed portion of Component 5.

CAMS-82844

$8715 \pm 35$

SON 348/H 114-9-C

$\delta^{13} \mathrm{C}=-0.1 \%$

M. californianus shell fragment, column sample, lower portion of Stratum VIII, Level 24, $250-260 \mathrm{~cm}$, sandy loam/midden mixed with shell.

Comment: 8978 (8934) 8884 cal BP $(1 \sigma)$. This sample came from the basal level of Component 2 and is the oldest marine shell ${ }^{14} \mathrm{C}$ age from the cave.

CAMS-82841

$8570 \pm 40$

SON 348/H 114-5-A

$\delta^{13} \mathrm{C}=0.5 \%$

Nearly complete $M$. californianus shell; see CAMS-86876 (above) for 200-210-cm level description.

Comment: 8903 (8844) $8769 \mathrm{cal} \mathrm{BP}(1 \sigma)$. This ${ }^{14} \mathrm{C}$ age is commensurate with our other shell ages from this level, and a Mytilus shell age (Schwaderer 1992, 1989-1992; $8610 \pm 110$ BP, BETA34844 ) collected in 1989 from the southeast wall of the test unit at a depth of $238-240 \mathrm{~cm}$.

CAMS-96618

$8565 \pm 30$

SON 348 114-13-B

$\delta^{13} \mathrm{C}=0.2 \%$

M. californianus shell fragment; see CAMS-96630 (above) for 190-200-cm level description.

Comment: 8898 (8839) 8771 cal BP (1 $\sigma)$. See CAMS-96630 (above) for comment.

CAMS-82842

$8550 \pm 35$

SON 348/H 114-5-D

$\delta^{13} \mathrm{C}=0.5 \%$

M. californianus shell fragment; see CAMS-86876 (above) for 200-210-cm level description.

Comment: 8890 (8825) 8749 cal BP (1 $\sigma)$.

CAMS-80457

$8520 \pm 35$

114-7-H

$\delta^{13} \mathrm{C}=0.1 \%$

M. californianus shell fragment; see CAMS-86877 (above) for 230-240-cm level description.

Comment: 8871 (8775) 8690 cal BP (1 б).

CAMS-80458

$8495 \pm 35$

114-7-F

$\delta^{13} \mathrm{C}=0.1 \%$

M. californianus shell fragment; see CAMS-86877 (above) for 230-240-cm level description.

Comment: 8854 (8744) 8637 cal BP (1 б).

\section{CAMS-82843}

$8470 \pm 35$

SON 348/H 114-9-A

$\delta^{13} \mathrm{C}=0.1 \%$

M. californianus shell fragment; see CAMS-82844 (above) for 250-260-cm level description.

Comment: 8833 (8691) 8605 cal BP (1 $\sigma)$. 
CAMS-80459

$8430 \pm 35$

114-8-B

$\delta^{13} \mathrm{C}=0.2 \%$

Nearly complete $M$. californianus shell; see CAMS-86880 (above) for 240-250-cm level description.

Comment: 8711 (8620) 8575 cal BP (1 $\sigma)$.

CAMS-80460

$8300 \pm 30$

114-8-C

$\delta^{13} \mathrm{C}=0.2 \%$

Nearly complete $M$. californianus shell; see CAMS-86880 (above) for 240-250-cm level description.

Comment: $8537(8460) 8415 \mathrm{cal}$ BP $(1 \sigma)$. This ${ }^{14} \mathrm{C}$ age overlaps at $1 \sigma$ with a shell age (CAMS80456, below) from the $230-240-\mathrm{cm}$ level.

CAMS-80456

$8285 \pm 45$

114-7-A

$\delta^{13} \mathrm{C}=-0.1 \%$

Nearly complete $M$. californianus shell; see CAMS-86877 (above) for 230-240-cm level description.

Comment: 8534 (8443) 8397 cal BP $(1 \sigma)$. This date is consistent with the ${ }^{14} \mathrm{C}$ age (Schwaderer 1992, 1989-1992; $8270 \pm 110$ BP, BETA-37473) of a Mytilus shell collected in 1989 at a depth of $200-205 \mathrm{~cm}$ from the column sample location along the southeast wall.

CAMS-82839

$5340 \pm 35$

SON 348/H 114-4-C

$\delta^{13} \mathrm{C}=0.1 \%$

Nearly complete $M$. californianus shell; see CAMS-86873 (above) for 160-170-cm level description.

Comment: 5469 (5444) 5354 cal BP (1 $\sigma)$. See CAMS-86873 (above) for comment.

CAMS-82840

$\mathbf{5 3 2 0} \pm \mathbf{3 5}$

SON 348/H 114-4-G

$\delta^{13} \mathrm{C}=0.2 \%$

Nearly complete $M$. californianus shell; see CAMS-86873 (above) for 160-170-cm level description.

Comment: 5457 (5433) 5320 cal BP (1 б).

CAMS-82838

$5290 \pm 35$

SON 348/H 114-4-A

$\delta^{13} \mathrm{C}=-0.1 \%$

Nearly complete $M$. californianus shell; see CAMS-86873 (above) for 160-170-cm level description.

Comment: 5440 (5327) 5305 cal BP (1 б).

CAMS-96615

$5245 \pm 30$

SON 348 114-10-A

$\delta^{13} \mathrm{C}=1.2 \%$

M. californianus shell fragment; see CAMS-96627 (above) for 140-150-cm level description.

Comment: 5324 (5304) 5285 cal BP (1 б).

CAMS-83039

$\mathbf{5 2 1 5} \pm \mathbf{3 5}$

SON 348/H 114-3-H

$\delta^{13} \mathrm{C}=0.6 \%$

M. californianus shell fragment; see CAMS-86871 (above) for 110-120-cm level description.

Comment: 5310 (5289) $5264 \mathrm{cal} \mathrm{BP}(1 \sigma)$. This ${ }^{14} \mathrm{C}$ age overlaps at $1 \sigma$ with a shell age (CAMS96615 , above) obtained from the $140-150-\mathrm{cm}$ level, but is older than a shell age (CAMS-83038, below) from the same level.

\section{CAMS-96617}

$5130 \pm 30$

SON 348 114-12-B

$\delta^{13} \mathrm{C}=-0.1 \%$

Complete M. californianus shell; see CAMS-96629 (above) for 170-180-cm level description. 
Comment: 5260 (5217) 5071 cal BP (1 б). See CAMS-96629 (above) for comment.

\section{CAMS-96616}

$5115 \pm 25$

SON 348 114-11-G

$\delta^{13} \mathrm{C}=-0.2 \%$

M. californianus shell fragment; see CAMS-96628 (above) for 150-160-cm level description.

Comment: $5243(5200) 5054$ cal BP $(1 \sigma)$. This date is in accord with a Mytilus shell ${ }^{14} \mathrm{C}$ age (Schwaderer 1992, 1989-1992; $5050 \pm 90$ BP, Beta-37472) obtained from the column sample location at a depth of $110-120 \mathrm{~cm}$.

\section{CAMS-83038}

$4560 \pm 35$

SON 348/H 114-3-G

$\delta^{13} \mathrm{C}=0.4 \%$

M. californianus shell fragment; see CAMS-86871 (above) for 110-120-cm level description.

Comment: 4438 (4407) $4371 \mathrm{cal}$ BP $(1 \sigma)$. This ${ }^{14} \mathrm{C}$ age postdates the shell ages from lower levels (see above) and a shell age (CAMS-83039, above) from the same 110-120-cm level.

\section{CAMS-83037}

$4490 \pm 25$

SON 348/H 114-3-D

$\delta^{13} \mathrm{C}=0.0 \%$

Nearly complete $M$. californianus shell; see CAMS-86871 (above) for 110-120-cm level description.

Comment: 4375 (4333) 4262 cal BP (1 $\sigma)$. See CAMS-83038 (above) for comment.

\section{CAMS-80453}

114-1-D

$3890 \pm 35$

M. californianus shell fragment; see CAMS-86867 (above) for 60-70-cm level description.

Comment: $3566(3517) 3459 \mathrm{cal} \mathrm{BP}(1 \sigma)$. This ${ }^{14} \mathrm{C}$ age postdates all the shell ages from levels above $110 \mathrm{~cm}$ and is the earliest shell date from Component 5.

\section{CAMS-82836}

$3740 \pm 35$

SON 348/H 114-1-C

$\delta^{13} \mathrm{C}=-0.1 \%$

Nearly complete $M$. californianus shell; see CAMS-86867 (above) for 60-70-cm level description.

Comment: 3383 (3350) $3318 \mathrm{cal} \mathrm{BP}(1 \sigma)$. This ${ }^{14} \mathrm{C}$ age is commensurate with a shell age (CAMS80453 , above) from the same level.

CAMS-82837

$3660 \pm 35$

SON 348/H 114-2-N

$\delta^{13} \mathrm{C}=1.0 \%$

M. californianus shell fragment; see CAMS-86868 (above) for 90-100-cm level description.

Comment: 3328 (3261) 3203 cal BP (1 $\sigma)$.

CAMS-80452

$3635 \pm 35$

114-1-A

$\delta^{13} \mathrm{C}=0.2 \%$

Nearly complete $M$. californianus shell; see CAMS-86867 (above) for 60-70-cm level description.

Comment: 3298 (3235) 3190 cal BP (1 б).

CAMS-80455

$3620 \pm 30$

114-2-M

$\delta^{13} \mathrm{C}=0.3 \%$

M. californianus shell fragment; see CAMS-86868 (above) for 90-100-cm level description.

Comment: 3260 (3210) 3164 cal BP $(1 \sigma)$. This is the same ${ }^{14} \mathrm{C}$ age (Schwaderer 1992; $3620 \pm 100$ BP, Beta-34837) obtained in 1989 from a Saxidomus shell at a depth of $62 \mathrm{~cm}$ near the column sample location. 
CAMS-80454

$3585 \pm 35$

114-2-A

$\delta^{13} \mathrm{C}=0.4 \%$

Nearly complete $M$. californianus shell; see CAMS-86868 (above) for 90-100-cm level description.

Comment: 3222 (3166) 3107 cal BP (1 б).

Duncan's Landing (CA-SON-348/H), Locus B (Open-air Midden)

CAMS-91667

$1805 \pm 30$

SON 348 CS-L34-1

$\delta^{13} \mathrm{C}=-25.4 \%$

Small charcoal fragment, Unit F, column sample, upper portion of Stratum V, Level 34, 166-170 cm, compact sandy loam.

Comment: 1815 (1713) 1635 cal BP (1 $\sigma)$. This sample is from the lower levels of Component A. It is a non-twig sample and may represent old wood brought to the site and used by the occupants.

\section{CAMS-90387}

$1210 \pm 30$

SON 348 CS-L25-1

$\delta^{13} \mathrm{C}=-23.9 \%$

Small charcoal fragment, Unit F, column sample, middle portion of Stratum IV, Level 25, 121-125 cm, compact shell lens of silty loam mixed with moderate midden.

Comment: $1174(1169,1157,1148) 1064 \mathrm{cal} \mathrm{BP}(1 \sigma)$. This date marks the initial date of occupation for Component A.

\section{CAMS-90386}

SON 348 CS-L24-1

$1085 \pm 30$

$\delta^{13} \mathrm{C}=-26.3 \%$

Small charcoal fragment, Unit F, column sample, upper portions of Stratum IV, Level 24, 116-120 cm; see CAMS-90387 (above) for description.

Comment: 1050 (970) 954 cal BP $(1 \sigma)$. This ${ }^{14} \mathrm{C}$ age overlaps at $2 \sigma$ with a charcoal sample (CAMS-91653, below) from the 96-100-cm level.

\section{CAMS-91653}

SON 348 CS-L20

$1025 \pm 30$
$\delta^{13} \mathrm{C}=-23.9 \%$

Burnt twig fragment, Unit F, column sample, Stratum III, Level $20,96-100 \mathrm{~cm}$, shell lens of silty loam mixed with heavy midden and shell fragments.

Comment: 956 (933) 927 cal BP ( $1 \sigma)$. The sample is from the mixed levels at the interface $(85-100 \mathrm{~cm})$ of components $\mathrm{A}$ and $\mathrm{B} 1$ and is commensurate with the other charcoal ${ }^{14} \mathrm{C}$ ages from below $100 \mathrm{~cm}$.

\section{CAMS-90388}

$$
\begin{array}{r}
960 \pm 30 \\
\delta^{13} \mathrm{C}=-24.8 \%
\end{array}
$$

SON 348 CS-L26

Small charcoal fragment, Unit F, column sample, middle portion of Stratum IV, Level 26, 126-130 cm; see CAMS-90387 (above) for description.

Comment: 928 (916) $795 \mathrm{cal} \mathrm{BP}(1 \sigma)$.

Beta-140865

$$
\begin{array}{r}
830 \pm 50 \\
\delta^{13} \mathrm{C}=-26.3 \%
\end{array}
$$

SON 348/H \#3

Several burnt twig fragments; see CAMS-90388 (above) for the 126-130-cm level description.

Comment: 787 (732) $687 \mathrm{cal} \mathrm{BP} \mathrm{(1} \mathrm{\sigma ).}$ 
CAMS-90385

$$
\begin{array}{r}
635 \pm 35 \\
\delta^{13} \mathrm{C}=-24.4 \%
\end{array}
$$

SON 348 CS-L8-3

Small charcoal fragment, Unit F, column sample, upper portions of Stratum II, Level 8, 36-40 cm, shell lens of silty loam mixed with heavy midden, fire-altered rock, and charcoal.

Comment: $653(647,582,567) 557 \mathrm{cal} \mathrm{BP}(1 \sigma)$. This ${ }^{14} \mathrm{C}$ age establishes the initial occupation of Component $\mathrm{B} 1$ and overlaps at $1 \sigma$ with charcoal ${ }^{14} \mathrm{C}$ ages from the same level (Beta-140863, below) and from the 56-60-cm level (CAMS-91650, below).

\section{CAMS-91650}

$630 \pm 30$

SON 348 CS-L12-1

$\delta^{13} \mathrm{C}=-25.7 \%$

Charcoal fragment, Unit F, column sample, lower portions of Stratum II, Level $12,56-60 \mathrm{~cm}$; see CAMS-90385 (above) for description.

Comment: $651(646,583,565) 557$ cal BP $(1 \sigma)$.

Beta-140863

$\mathbf{6 0 0} \pm 50$

SON 348/H \#1

$\delta^{13} \mathrm{C}=-22.7 \%$

Several charcoal pieces and burnt twig fragments; see CAMS-90385 (above) for the 36-40-cm level description.

Comment: $650(623,604,557) 544$ cal BP $(1 \sigma)$.

CAMS-91652

$\mathbf{5 2 5} \pm \mathbf{3 0}$

SON 348 CS-L18-1

$\delta^{13} \mathrm{C}=-27.7 \%$

Burnt twig fragment, Unit F, column sample upper portions of Stratum III, Level 18, 86-90 cm; see CAMS-91653 (above) for description.

Comment: 547 (536) $521 \mathrm{cal}$ BP $(1 \sigma)$. The sample is from the interface mixing zone between components $\mathrm{A}$ and $\mathrm{B} 1$ and is compatible with the charcoal ${ }^{14} \mathrm{C}$ ages from higher levels.

CAMS-91651

$465 \pm 30$

SON 348 CS-L14-1

$\delta^{13} \mathrm{C}=-23.6 \%$

Charcoal fragment, Unit F, column sample, lower portions of Stratum II, Level 14, 66-70 cm; see CAMS-90385 (above) for description.

Comment: 524 (512) $506 \mathrm{cal} \mathrm{BP} \mathrm{(1} \mathrm{\sigma ).}$

CAMS-90384

$460 \pm 30$

SON 348 CS-L8-2

$\delta^{13} \mathrm{C}=-24.4 \%$

Charcoal fragment; see CAMS-90385 (above) for the 36-40-cm level description.

Comment: 522 (511) 505 cal BP (1 $\sigma)$.

CAMS-90383

$390 \pm 30$

SON 348 CS-L8-1

$\delta^{13} \mathrm{C}=-24.5 \%$

Charcoal fragment; see CAMS-90385 (above) for the 36-40-cm level description.

Comment: 503 (474) $341 \mathrm{cal} \mathrm{BP}(1 \sigma)$. This is the youngest charcoal ${ }^{14} \mathrm{C}$ age from Component B1.

CAMS-90254

SON 348 CS-L26-A

$1500 \pm 35$

$\delta^{13} \mathrm{C}=-0.5 \%$

M. californianus shell fragment; see CAMS-90388 (above) for the 126-130-cm level description.

Comment: 759 (723) $683 \mathrm{cal} \mathrm{BP}(1 \sigma)$. This is the oldest shell ${ }^{14} \mathrm{C}$ age from Component $\mathrm{A}$. 
CAMS-90253

$1460 \pm 30$

SON 348 CS-L25-A

$\delta^{13} \mathrm{C}=0.1 \%$

M. californianus shell fragment; see CAMS-90387 (above) for the 121-125-cm level description.

Comment: 815 (762) 801 cal BP (1 б).

CAMS-90252

$1435 \pm 30$

SON 348 CS-L24-A

$\delta^{13} \mathrm{C}=0.4 \%$

M. californianus shell fragment; see CAMS-90386 (above) for the 116-120-cm level description.

Comment: 732 (697) $667 \mathrm{cal}$ BP (1 б).

\section{CAMS-91666}

$1385 \pm 30$

SON 348 CS-L34-A

$\delta^{13} \mathrm{C}=0.3 \%$

M. californianus shell fragment; see CAMS-91667 (above) for the 166-170-cm level description.

Comment: $688(661) 645 \mathrm{cal} \mathrm{BP}(1 \sigma)$. This ${ }^{14} \mathrm{C}$ age suggests that remains from Component $\mathrm{A}$ reach a depth of $170 \mathrm{~cm}$.

CAMS-90250

$1280 \pm 30$

SON 348 CS-L14-A

$\delta^{13} \mathrm{C}=-0.1 \%$

Nearly complete $M$. californianus shell; see CAMS-91651 (above) for the 66-70-cm level description.

Comment: 630 (609) $548 \mathrm{cal}$ BP $(1 \sigma)$. This is the oldest shell ${ }^{14} \mathrm{C}$ age from Component B1.

CAMS-91649

$1275 \pm 35$

SON 348 CS-L12-A

$\delta^{13} \mathrm{C}=0.3 \%$

M. californianus shell fragment; see CAMS-91650 (above) for the 56-60-cm level description.

Comment: 630 (601) 544 cal BP (1 $\sigma)$.

Beta-140866

$1260 \pm 60$

SON 348/H \#4

$\delta^{13} \mathrm{C}=0.5 \%$

Eight sea mussel shell fragments (44.1 g); see CAMS-90388 (above) for the 126-130-cm level description.

Comment: 634 (559) $523 \mathrm{cal} \mathrm{BP}(1 \sigma)$. This ${ }^{14} \mathrm{C}$ age overlaps at $1 \sigma$ with shell ages (CAMS-90250 and CAMS-91649, above) from Component B1.

CAMS-90251

$1165 \pm 30$

SON 348 CS-L18-A

$\delta^{13} \mathrm{C}=-0.9 \%$

M. californianus shell fragment; see CAMS-91652 (above) for the 86-90-cm level description.

Comment: $527(508) 491 \mathrm{cal} \mathrm{BP}(1 \sigma)$. The sample is from the interface mixing zone and is consistent with shell ${ }^{14} \mathrm{C}$ ages from Component $\mathrm{B} 1$.

CAMS-90247

$1140 \pm 30$

SON 348 CS-L8-A

$\delta^{13} \mathrm{C}=0.2 \%$

M. californianus shell fragment; see CAMS-90385 (above) for the 36-40-cm level description.

Comment: 514 (497) 474 cal BP $(1 \sigma)$.

CAMS-90248

$1130 \pm 30$

SON 348 CS-L8-B

$\delta^{13} \mathrm{C}=-0.2 \%$

M. californianus shell fragment; see CAMS-90385 (above) for the 36-40-cm level description.

Comment: 509 (492) 467 cal BP (1 $\sigma)$. 
Beta-140864

$1000 \pm 60$

SON 348/H \#2

$\delta^{13} \mathrm{C}=0.5 \%$

Nine sea mussel shell fragments (45.3 g); see CAMS-90385 (above) for the $36-40$-cm level description.

Comment: 448 (394) 297 cal BP (1 б).

CAMS-90249

$990 \pm 40$

SON 348 CS-L8-C

$\delta^{13} \mathrm{C}=-0.4 \%$

M. californianus shell fragment; see CAMS-90385 (above) for the 36-40-cm level description.

Comment: 425 (371) 302 cal BP (1 $\sigma)$.

CAMS-91654

$790 \pm 30$

SON 348 CS-L20-A

$\delta^{13} \mathrm{C}=-0.1 \%$

M. californianus shell fragment; see CAMS-91653 (above) for the 96-100-cm level description.

Comment: 241 (139) $101 \mathrm{cal} \mathrm{BP}(1 \sigma)$. The sample is from the interface mixing zone. This ${ }^{14} \mathrm{C}$ age is in accord with the shell ages from the upper levels (Component B1).

\section{Ocean Springs (CA-SON-2378H), Locus SM2}

CAMS-91672

$4530 \pm 30$
$\delta^{13} \mathrm{C}=-22.7 \%$

BML SM2-F1-L1-1

$\delta^{13} \mathrm{C}=-22.7 \%$

Small charcoal fragment, Unit A, Feature 1, Level 1, 7-20 cm, sand with oxidized patches mixed with burnt and unburnt shell, charcoal, bone, and fire-altered rock.

Comment: 5301 (5156) 5053 cal BP (1 $\sigma)$. This calibrated spread is commensurate with other charcoal ages from Feature 1 (Beta-140870, below) and Feature 2 (CAMS-91673, below).

CAMS-91673

$4505 \pm 30$
$\delta^{13} \mathrm{C}=-26.1 \%$

BML SM2-F2-L3-1

Small, sandy charcoal fragment, Unit A, Feature 2, Level $3,44-57 \mathrm{~cm}$, sand mixed with shell fragments, charcoal, ash, and cooking stones.

Comment: 5292 (5289, 5155, 5150, 5097, 5091) 5049 cal BP (1 $\sigma)$.

Beta-140870

$$
\begin{array}{r}
4420 \pm 60 \\
\delta^{13} \mathrm{C}=-22.6 \%
\end{array}
$$

BML SM2 \#1

Several charcoal pieces and small burned twig fragments, Unit A, Feature 1; see CAMS-91672 (above) for description.

Comment: $5213(5030,5017,4978) 4871 \mathrm{cal} \mathrm{BP}(1 \sigma)$.

CAMS-86883

$5095 \pm 40$

BML SM2-A-L3

$\delta^{13} \mathrm{C}=0.2 \%$

Complete M. californianus shell, Unit A, Feature 2; see CAMS-91673 (above) for description.

Comment: $5233(5113,5101,5079) 5029 \mathrm{cal} \mathrm{BP}(1 \sigma)$. This ${ }^{14} \mathrm{C}$ age is compatible with the shell ages from Feature 2 (Beta-140871, below) and from the Unit A, Level 1 matrix (CAMS-86884, below).

CAMS-86884

$5030 \pm 35$

BML SM2-A-L1

$\delta^{13} \mathrm{C}=0.8 \%$

M. californianus shell fragment, Unit A, unit matrix, Level 1, 0-20 cm, sand mixed with fragmented shell.

Comment: 5046 (4993) 4948 cal BP (1 $\sigma)$. 
Beta-140871

$4930 \pm 80$

BML SM2 \#2

$\delta^{13} \mathrm{C}=0.8 \%$

Eight shell fragments (48.5 g), Unit A, Feature 1; see CAMS-91672 (above) for description.

Comment: 4970 (4852) 4809 cal BP (1 $\sigma)$.

\section{Ocean Springs (CA-SON-2378H), Locus SM1}

\section{Beta-153356}

$3970 \pm 40$

BML SM1 \#1-A

$\delta^{13} \mathrm{C}=-24.9 \%$

Charcoal fragment, Unit A (center), matrix sub-sample, upper portions of Level 3, $41-45 \mathrm{~cm}$, sand mixed with sporadic fragmented shell.

Comment: 4507 (4419) 4410 cal BP $(1 \sigma)$. This ${ }^{14} \mathrm{C}$ age postdates the charcoal ages from Ocean Springs, Locus SM2.

\section{Beta-153357}

$4650 \pm 60$

BML SM1 \#2-A

$\delta^{13} \mathrm{C}=0.1 \%$

Eleven shell fragments (15.4 g); see BETA-153356 (above) for 41-45-cm description.

Comment: 4604 (4515) 4423 cal BP $(1 \sigma)$. This ${ }^{14} \mathrm{C}$ age postdates the shell ages from Locus SM2.

This sample required extended counting time for ${ }^{14} \mathrm{C}$ content.

\section{Two Seals (CA-SON-1735), Locus SM1}

\section{CAMS-91664}

$$
\begin{array}{r}
4060 \pm 30 \\
\delta^{13} \mathrm{C}=-27.6 \%
\end{array}
$$

SON 1735 E-F3-L2-1

Small burned twig fragment, units E and F, Feature 3, Level 2, 21-40 cm, sand mixed with charcoal, burnt wood, ash, weathered shell, and fire-altered rock.

Comment: $4569(4564,4564,4527) 4448$ cal BP $(1 \sigma)$. The sample is from the lower portion of the feature and predates a bulk charcoal sample (Beta-140869, below) from the entire feature.

CAMS-91663

$4005 \pm 30$

SON 1735 C-F2-L2-1

$\delta^{13} \mathrm{C}=-24.7 \%$

Small burned twig fragment, Unit C, Feature 2 (south area), Level 2, 26-40 cm, sand mixed with charcoal, ash, weathered shell, and fire-altered rock.

Comment: $4520(4503,4488,4422) 4419 \mathrm{cal}$ BP $(1 \sigma)$. This ${ }^{14} \mathrm{C}$ age overlaps at $2 \sigma$ with a charcoal age from Feature 3 (CAMS-91664, above).

Beta-140869

$3840 \pm 80$

SON 1735 \#1

$\delta^{13} \mathrm{C}=-25.8 \%$

Bulk sample of charcoal pieces ( $15 \mathrm{~g}$ ), Unit F, Feature 3, levels 1 and 2, 6-40 cm; see CAMS-91664 (above) for description.

Comment: 4410 (4240) 4094 cal BP (1 $\sigma)$.

CAMS-91662

$3800 \pm 30$

SON 1735 B-F1-L1-1

$\delta^{13} \mathrm{C}=-25.6 \%$

Small charcoal fragment, Unit B, Feature 1, Level 1, 5-20 cm, sand mixed with charcoal, weathered shell, and fire-altered rock.

Comment: $4237(4219,4207,4174,4174,4152) 4097 \mathrm{cal} \mathrm{BP}(1 \sigma)$. This ${ }^{14} \mathrm{C}$ age overlaps at $2 \sigma$ with a charcoal age (Beta-140869, above) from Feature 3. 
CAMS-91671

$4670 \pm 30$

SON 1735 F-L2-A

$\delta^{13} \mathrm{C}=0.3 \%$

M. californianus shell fragment, Unit F, unit matrix, Level 2, 21-40 cm, sand mixed with sporadic shell fragments.

Comment: 4581 (4529) $4502 \mathrm{cal}$ BP $(1 \sigma)$. This ${ }^{14} \mathrm{C}$ age is the same age as a shell (CAMS-91669, below) from the Unit B matrix.

CAMS-91669

$4670 \pm 35$

SON 1735 B-L2-A

$\delta^{13} \mathrm{C}=-0.1 \%$

M. californianus shell fragment, Unit B, unit matrix, Level $2,21-40 \mathrm{~cm}$, sand mixed with sporadic shell fragments.

Comment: 4600 (4529) 4499 cal BP (1 $\sigma)$.

CAMS-91670

$4620 \pm 30$

SON 1735 C-F2-SA-L2-A

$\delta^{13} \mathrm{C}=1.1 \%$

M. californianus shell fragment, Unit C, Feature 2 (south area); see CAMS-91663 for $26-40-\mathrm{cm}$ level description.

Comment: 4519 (4490) 4419 cal BP (1 б).

\section{Salmon Creek Beach (CA-SON-284), Locus SM1}

CAMS-91658

$3935 \pm 30$

SON 284 SM1-B-L2-1

$\delta^{13} \mathrm{C}=-25.5 \%$

Small charcoal fragment, Unit B (center), matrix sub-sample, upper portions of Level $2,11-15 \mathrm{~cm}$, sand and slightly silty/midden mixed with whole and fragmented shells.

Comment: $4418(4412) 4303$ cal BP $(1 \sigma)$. This ${ }^{14} \mathrm{C}$ age marks the initial occupation of Locus SM1 and overlaps with CAMS-91668 (below) at $1 \sigma$.

CAMS-91668

$3925 \pm 45$

SON 284 SM1-C-L5-1

$\delta^{13} \mathrm{C}=-23.2 \%$

Small charcoal fragment, Unit C (center), matrix sub-sample, upper portions of Level 5, $41-45 \mathrm{~cm}$, sand and slightly silty/midden mixed with fragmented shells.

Comment: 4419 (4410) 4295 cal BP (1 б).

CAMS-86881

$4465 \pm 35$

SON 284 SM1-B-L2

$\delta^{13} \mathrm{C}=0.1 \%$

$M$. californianus shell fragment, Unit B, unit matrix; see CAMS-91658 (above) for the 11-20-cm level description.

Comment: 4350 (4280) 4225 cal BP (1 $\sigma)$.

CAMS-86882

$4345 \pm 35$

SON 284 SM1-C-L11

$\delta^{13} \mathrm{C}=-0.6 \%$

M. californianus shell fragment, Unit C, unit matrix, Level $11,101-110 \mathrm{~cm}$, sand.

Comment: 4153 (4098) 4065 cal BP (1 $\sigma)$. 
Salmon Creek Beach (CA-SON-284), Locus SM2

CAMS-91660

$3780 \pm 45$
$\delta^{13} \mathrm{C}=-23.2 \%$

SON 284 SM2-A-L2-1

Small burned twig fragment, Unit A (center), matrix sub-sample, upper portions of Level 2, $11-15 \mathrm{~cm}$, slightly silty sand mixed with fragmented shells.

Comment: 4235 (4149) 4088 cal BP (1 $\sigma)$.

CAMS-91661

$4530 \pm 30$

SON 284 SM2-A-L10-A

$\delta^{13} \mathrm{C}=-0.1 \%$

M. californianus shell fragment, Unit A, unit matrix, Level $10,91-95 \mathrm{~cm}$, sand.

Comment: 4411 (4385) 4337 cal BP (1 б).

CAMS-91659

$4415 \pm 30$

SON 284 SM2-A-L2-A

$\delta^{13} \mathrm{C}=0.1 \%$

M. californianus shell fragment, Unit A, unit matrix; see CAMS-91660 (above) for the 11-20-cm level description.

Comment: 4257 (4218) $4146 \mathrm{cal} \mathrm{BP}(1 \sigma)$. This ${ }^{14} \mathrm{C}$ age is consistent with the shell ages from Locus SM1, above.

\section{Mussel Point (CA-SON-327), Locus SM1}

\section{CAMS-91656}

SON 327 CS-L5-1

$2285 \pm 30$
$\delta^{13} \mathrm{C}=-23.6 \%$

Small charcoal fragment, column sample, Level $5,71-75 \mathrm{~cm}$, sand mixed with moderate midden, ash, charcoal, and fragmented shell.

Comment: 2344 (2334) $2211 \mathrm{cal} \mathrm{BP}(1 \sigma)$. This ${ }^{14} \mathrm{C}$ age overlaps at $2 \sigma$ with a shell age (CAMS91657, below) from the 76-80-cm level.

CAMS-91657

$2235 \pm 35$

SON 327 CS-L6-1

$\delta^{13} \mathrm{C}=-23.8 \%$

Small charcoal fragment, column sample, Level $6,76-80 \mathrm{~cm}$; see CAMS-91656 (above) for description.

Comment: 2330 (2307, 2223, 2208, 2186, 2184) 2155 cal BP (1 б).

CAMS-91655

$225 \pm 30$

SON 327 A-L3-1

$\delta^{13} \mathrm{C}=-25.0 \%$

Burned twig fragment, Unit A, matrix sub-sample, upper portions of Level 3, 21-25 cm, silty sand mixed with fragmented shell.

Comment: $302(287,164,164,157,156) 0^{* 1}$ cal BP $(1 \sigma)$. This sample can be rejected by the criterion of Chauvenet (see Long and Rippeteau 1974). It represents modern charcoal introduced into the upper levels of Unit A.

1* - represents a negative ${ }^{14} \mathrm{C}$ age BP as reported by CALIB v 4.3 (Stuiver and Reimer 1993). 
CAMS-90256

$2755 \pm 35$

SON 327 CS-L5-A

$\delta^{13} \mathrm{C}=0.7 \%$

M. californianus shell fragment, column sample, Level 5, 71-75 cm; see CAMS-91656 (above) for description.

Comment: 2175 (2129) $2093 \mathrm{cal}$ BP $(1 \sigma)$. This shell ${ }^{14} \mathrm{C}$ age overlaps at $1 \sigma$ with shell ages from the 76-80-cm level (CAMS-90257, below) and the 81-85-cm level (Beta-153358, below).

CAMS-90257

$2735 \pm 40$

SON 327 CS-L6-A

$\delta^{13} \mathrm{C}=1.0 \%$

M. californianus shell fragment, column sample, Level 6, 76-80 cm; see CAMS-91656 (above) for description.

Comment: 2152 (2112) 2052 cal BP (1 $\sigma)$.

Beta-153358

$2730 \pm 40$

SON 327 \#1-A

$\delta^{13} \mathrm{C}=-0.3 \%$

Eight $M$. californianus shell fragments $(2.7 \mathrm{~g})$, column sample, Level $7,81-85 \mathrm{~cm}$, sand mixed with fragments of shell.

Comment: 2148 (2108) 2045 cal BP (1 $\sigma)$.

CAMS-90255

$2530 \pm 25$

SON 327 Unit A-L3-A

$\delta^{13} \mathrm{C}=0.3 \%$

M. californianus shell fragment, Unit A, unit matrix, Level 3, 21-30 cm; see CAMS-91655 (above) for description.

Comment: 1896 (1866) 1826 cal BP (1 $\sigma)$.

Kili (CA-SON-299), Unknown Provenience

CAMS-100074

$2610 \pm 25$

SON 299 1-200631-5-E

$\delta^{13} \mathrm{C}=-0.5 \%$

M. californianus shell fragment.

Comment: 1988 (1949) 1917 cal BP $(1 \sigma)$. This is the oldest shell age from Kili.

CAMS-100075

$2525 \pm 35$

SON 299 1-200631-7-G

$\delta^{13} \mathrm{C}=0.9 \%$

Nearly complete $M$. californianus shell.

Comment: 1899 (1863) 1817 cal BP $(1 \sigma)$. This ${ }^{14} \mathrm{C}$ age overlaps at $1 \sigma$ with CAMS-96624 and CAMS-96622, below.

CAMS-96624

$2520 \pm 30$

SON 299 1-200631-6-F

$\delta^{13} \mathrm{C}=0.0 \%$

Nearly complete $M$. californianus shell.

Comment: 1890 (1859) 1816 cal BP (1 $\sigma)$.

CAMS-96622

$2490 \pm 30$

SON 299 1-200631-1-A

$\delta^{13} \mathrm{C}=0.0 \%$

Complete $M$. californianus shell.

Comment: 1864 (1820) 1788 cal BP (1 $\sigma)$. 
CAMS-100078

$2450 \pm 30$

SON 299 1-200631-10-J

$\delta^{13} \mathrm{C}=0.4 \%$

M. californianus shell fragment.

Comment: $1818(1785) 1721 \mathrm{cal}$ BP $(1 \sigma)$. This ${ }^{14} \mathrm{C}$ age overlaps at $1 \sigma$ with CAMS-100072 and CAMS-96623, below.

CAMS-100072

$2440 \pm 35$

SON 299 1-200631-2-B

$\delta^{13} \mathrm{C}=0.6 \%$

Nearly complete $M$. californianus shell.

Comment: 1815 (1770) 1708 cal BP (1 б).

CAMS-96623

$2420 \pm 30$

SON 299 1-200631-4-D

$\delta^{13} \mathrm{C}=-0.6 \%$

Nearly complete $M$. californianus shell.

Comment: 1797 (1730) 1696 cal BP (1 б).

CAMS-100077

SON 299 1-200631-9-I

$2395 \pm 30$

Nearly complete $M$. californianus shell.

$\delta^{13} \mathrm{C}=-0.6 \%$

Comment: $1758(1705) 1681 \mathrm{cal} \mathrm{BP}(1 \sigma)$. This ${ }^{14} \mathrm{C}$ age overlaps at $1 \sigma$ with CAMS-96623 (above) and CAMS-100073 (below) and is compatible with the shell ages from Trench F (below).

CAMS-100073

$2390 \pm 35$

SON 299 1-200631-3-C $\delta^{13} \mathrm{C}=0.5 \%$

Nearly complete $M$. californianus shell.

Comment: 1755 (1701) 1670 cal BP (1 б).

CAMS-100076

$2265 \pm 30$

SON 299 1-200631-8-H

$\delta^{13} \mathrm{C}=1.1 \%$

Nearly complete $M$. californianus shell.

Comment: 1594 (1543) 1515 cal BP (1 б).

Kili (CA-SON-299), Trench F

CAMS-100071

$2380 \pm 35$

SON 299 1-107342-1-A

M. californianus shell fragment, Pit F-5, 48-60".

$\delta^{13} \mathrm{C}=1.1 \%$

Comment: 1733 (1694) 1629 cal BP $(1 \sigma)$. This is the oldest shell ${ }^{14} \mathrm{C}$ age from Trench F.

CAMS-96621

$2375 \pm 35$

SON 299 1-107336-1-A

$\delta^{13} \mathrm{C}=0.5 \%$

Nearly complete $M$. californianus shell, Pit F-2, 48-60".

Comment: $1726(1690) 1624 \mathrm{cal} \mathrm{BP}(1 \sigma)$. This ${ }^{14} \mathrm{C}$ age overlaps at $1 \sigma$ with a shell age from the same depth (CAMS-100071, above) at Pit F-5, and with a shell age from the 36-48" level (CAMS100070, below) in the same pit (Pit F-2). 
CAMS-100070

$2360 \pm 35$

SON 299 1-107324-2-B

$\delta^{13} \mathrm{C}=0.8 \%$

Nearly complete $M$. californianus shell, Pit F-2, 36-48".

Comment: 1709 (1682) $1608 \mathrm{cal}$ BP $(1 \sigma)$. This ${ }^{14} \mathrm{C}$ age overlaps at $1 \sigma$ with shell ages from the 48-60" level (CAMS-96621, above) and from the 12-24" level (CAMS-96619 and CAMS100068, below).

CAMS-96619

$2335 \pm 25$

SON 299 1-107303-1-A

$\delta^{13} \mathrm{C}=0.5 \%$

Nearly complete $M$. californianus shell, Pit F-2, 12-24".

Comment: $1686(1626) 1592 \mathrm{cal} \mathrm{BP}(1 \sigma)$. This is the same ${ }^{14} \mathrm{C}$ age produced by another shell (CAMS-100068, below) from the same level.

CAMS-100068

SON 299 1-107303-2-B

$2335 \pm 35$

Nearly complete $M$. californianus shell, Pit F-2, 12-24".

$\delta^{13} \mathrm{C}=0.2 \%$

Comment: 1691 (1626) 1582 cal BP (1 $\sigma)$.

CAMS-100069

$2235 \pm 35$

SON 299 1-107312-1-A

$\delta^{13} \mathrm{C}=0.4 \%$

M. californianus shell fragment, Pit F-2, 24-36".

Comment: 1555 (1519) $1484 \mathrm{cal} \mathrm{BP}(1 \sigma)$. This ${ }^{14} \mathrm{C}$ age overlaps at $1 \sigma$ with a shell sample (CAMS96620 , below) from the $36-48$ " level.

\section{CAMS-96620}

$2230 \pm 30$

SON 299 1-107324-1-A

$\delta^{13} \mathrm{C}=0.7 \%$

Complete M. californianus shell, Pit F-2, 36-48".

Comment: 1546 (1517) $1483 \mathrm{cal}$ BP (1 $\sigma)$. This is the youngest shell age from Kili.

\section{Bodega Lagoon (CA-SON-322), Locus SM1}

CAMS-83043

$$
\begin{array}{r}
665 \pm 35 \\
\delta^{13} \mathrm{C}=-26.6 \%
\end{array}
$$

SON 322 676/001 \#1

$\delta^{13} \mathrm{C}=-26.6 \%$
$12,111-115 \mathrm{~cm}$,

Small burnt twig fragment, Unit D (northwest corner), matrix sub-samp
silty sand mixed with dark midden and densely packed shell fragments.

Comment: 661 (652) 565 cal BP $(1 \sigma)$. This non-twig sample can be rejected by the criterion of Chauvenet (see Long and Rippeteau 1974). It may represent old wood, possibly from a charred log located along the south wall of excavation Unit A, or may be intrusive from deeper deposits.

CAMS-90389

SON 322 675/001-L12-2

Very small burnt twig fregm sand mixed with dark midden and densely packed shell fragments.

Comment: $480(462,345,345) 325 \mathrm{cal} \mathrm{BP}(1 \sigma)$. This is the oldest accepted ${ }^{14} \mathrm{C}$ age for the upper levels of the deposit. 
CAMS-83042

$225 \pm 35$

SON 322 775/995 \#3

$\delta^{13} \mathrm{C}=-27.1 \%$

Burnt twig fragment, Unit E, unit matrix, Level 12, 141-150 cm, sand mixed with moderate midden and loose shell.

Comment: $303(287,164,164,157,156) 0^{*}$ cal BP $(1 \sigma)$. This ${ }^{14} \mathrm{C}$ age overlaps at $1 \sigma$ with a charcoal age from the same provenience (CAMS-86866, below). $\delta^{13} \mathrm{C}$ was estimated from CAMS83040, below.

\section{CAMS-86866}

$190 \pm 35$

SON 322 775/995-L12

$\delta^{13} \mathrm{C}=-27.1 \%$

Charcoal fragment, Unit E, unit matrix; see CAMS-83042 (above) for 141-150-cm level description.

Comment: $288\left(282,169,153,5,0^{*}, 0^{*}\right) 0^{*}$ cal BP $(1 \sigma) . \delta^{13} \mathrm{C}$ was estimated from CAMS-83040, below.

CAMS-83040

$175 \pm 35$

SON 322 775/995 \#1

$\delta^{13} \mathrm{C}=-27.1 \%$

Burnt twig fragment, Unit E, unit matrix; see CAMS-83042 (above) for 141-150-cm level description.

Comment: $284\left(281,275,270,183,180,171,151,10,0^{*}\right) 0^{*}$ cal BP $(1 \sigma)$. This ${ }^{14} \mathrm{C}$ age overlaps at $1 \sigma$ with CAMS-86866 (above) and CAMS-83041 (below).

CAMS-83041

SON 322 775/995 \#2

$160 \pm 35$

$\delta^{13} \mathrm{C}=-27.1 \%$

Burnt twig fragment, Unit E, unit matrix; see CAMS-83042 (above) for 141-150-cm level description.

Comment: 283 (267, 211, 206, 187, 175, 174, 174, 173, 145, 144, 144, 20, 18, 18, 16, 11, 0*) 0* cal BP $(1 \sigma) . \delta^{13} \mathrm{C}$ was estimated from CAMS-83040, above.

\section{Beta-140867}

$90 \pm 50$

SON 322 \#1

$\delta^{13} \mathrm{C}=-25.2 \%$

Several burnt twig fragments (18.4 g), Unit E, unit matrix; see CAMS-83042 (above) for 141-150cm level description.

Comment: $266\left(122,122,69,67,59,43,0^{*}\right) 0^{*}$ cal BP $(1 \sigma)$. The calibrated spread of this bulk sample date corresponds with other charcoal samples from the site, but may represent modern/historic charcoal (mean calibrated intercept $=69 \mathrm{cal} \mathrm{BP}$ ).

CAMS-80450

$1000 \pm 35$

775/995-L12 \#1

$\delta^{13} \mathrm{C}=0.6 \%$

M. californianus shell fragment, Unit E, unit matrix; see CAMS-83042 (above) for 141-150-cm level description.

Comment: 429 (394) $311 \mathrm{cal}$ BP (1 $\sigma)$. This is the oldest shell age from the upper levels of the deposit.

CAMS-82846

$895 \pm 35$

SON 322 676/001 \#1

$\delta^{13} \mathrm{C}=1.2 \%$

$M$. californianus shell fragment, Unit D (northwest corner), matrix sub-sample; see CAMS-83043 (above) for 111-115-cm level description.

Comment: 296 (276) $258 \mathrm{cal}$ BP ( $1 \sigma)$. This shell ${ }^{14} \mathrm{C}$ age overlaps at $1 \sigma$ with other shell ages from 141-150 cm at Unit E (CAMS-80451 and CAMS-82845, below). 


\section{CAMS-80451}

$865 \pm 40$

775/995-L12 \#2

$\delta^{13} \mathrm{C}=0.2 \%$

M. californianus shell fragment, Unit E, unit matrix; see CAMS-83042 (above) for 141-150-cm level description.

Comment: 283 (262) 237 cal BP $(1 \sigma)$. This is the same ${ }^{14} \mathrm{C}$ age as another shell (CAMS-82845, below) from this level.

\section{CAMS-82845}

$865 \pm 35$

SON 322 775/995 \#5

$\delta^{13} \mathrm{C}=0.5 \%$

Complete $M$. californianus shell, Unit E, unit matrix; see CAMS-83042 (above) for 141-150-cm level description.

Comment: 281 (262) 241 cal BP (1 $\sigma)$.

\section{Beta-140868}

$850 \pm 70$

SON 322 \#2

Five $M$. californianus shell fragments (59.2 g), Unit E, unit matrix; see CAMS-83042 (above) for 141-150-cm level description.

Comment: 289 (255) $131 \mathrm{cal} \mathrm{BP}(1 \sigma)$. 